\title{
BUCKET-SHAPED PENDANTS FROM THE SARMATAE ENVIRONMENT. A FEW NOTES ON THE ORIGIN, DATING AND USE OF THESE AMULETS IN THE BARBARIAN WORLD
}

VITALIE BÂRC

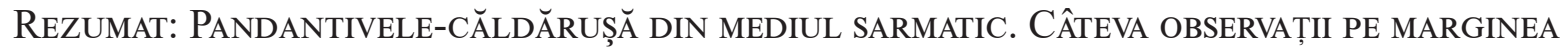 ORIGINII, DATĂRII ŞI UTILIZĂRII ACESTOR AMULETE ÎN LUMEA BARBARĂ}

Pandantivele-căldărușă au avut o largă răspândire în diverse medii culturale din spațiul cuprins între nordul-estul Mării Negre și Europa Centrală. Studiul de faţă încearcă, fără a avea pretenții de exhaustivitate, o analiză a pieselor de acest tip în mediul sarmatic.

Autorul examinează aceste pandantive din mediul sarmatic alături de cel din alte medii culturale, într-un context mai larg și constată că în mediul sarmatic pandantivele-căldărușă provin cu precădere din morminte de copii și femei, fiind întâlnite atât în morminte bogate, cât și în cele mai sărăcăcioase.

Autorul remarcă că cele mai timpurii exemplare de astfel de pandantive sunt din spațiul nord-pontic şi provin din complexe ce se datează în sec. II-I a. Chr., fapt ce sugerează, originea pandantivelor-căldărușă, alături de alte tipuri de pandantive, în regiunea nord-pontică. În sec. I a. Chr. aceste pandantive sunt prezente la scitii târzii și sarmați din nordul și nord-vestul Mării Negre, dar și în mediul geto-dacic și germanic (cultura Poieneşti-Lucășeuca).

Odată cu secolul I p. Chr. numărul pandantivelor-căldărușă crește semnificativ în mediul scitic târziu, sarmatic, geto-dacic, dar și în cadrul necropolelor orașelor și așezărilor din zona nord-pontică. Tot din această perioadă ele încep să fie atestate și în arealul culturii Przeworsk.

În urma analizei descoperirilor de pandantivele-căldărușă din mediul sarmatic s-a ajuns la concluzia că nu se poate vorbi de o utilizare intensă a lor de către sarmați, precum în cazul altor tipuri de pandantive. Autorul remarcă că marea majoritatea a pandantivelor-căldărușă din mediul sarmatic nord și nord-vest pontic sunt din morminte ce se datează în intervalul cronologic cuprins între mijlocul sec. I p. Chr. - începutul/primele decenii ale sec. II p. Chr. De asemenea s-a constatat că astfel de artefacte se întâlnesc rareori în morminte sarmatice din a doua jumătate a sec. II - prima jumătate a sec. III p. Chr., dar și că lipsesc în a doua etapă a perioadei sarmatice târzii (a doua jumătate a sec. III - sec. IV p. Chr.).

Ca urmare a analizei complexelor funerare sarmatice din Câmpia Panonică în care au fost descoperite pandantivecăldărușă se conchide că obiceiul purtării acestor pandantive de către femei și copii a fost adus în acest spațiu în a doua jumătate a sec. I p. Chr. de primele grupuri de sarmați aşezați în această regiune. Nu în ultimul rând s-a remarcat că în mediul sarmatic din acest areal geografic aceste artefacte au fost utilizate, într-o măsură mai mare sau mai mică, pe toată durata locuirii lor în acest areal geografic.

În final se conchide că utilizarea masivă a pandantivelor-căldărușă în sec. II -IV p. Chr. în diverse medii culturale din spațiul cuprins între nordul Mării Negre și Europa Centrală indică faptul că ele au devenit artefacte "supranaţionale", fiind produse și utilizate de diverse populații din acest areal geografic.

\section{ABSTRACT:}

Bucket-shaped pendants were broadly diffused in various cultural environments from the area comprised between the north-east of the Black Sea and Central Europe. This study attempts, without aiming at being exhaustive, to analyse the objects of this type within the Sarmatian environment.

The author examines these pendants from the Sarmatian environment compared to that of other cultural settings, within a broader context and concludes that in the Sarmatian environment, bucket-shaped pendants come mainly from either richly and poorly furnished children and women graves.

The author notes that earliest specimens of such pendants are found in the north-Pontic area and originate in features that date to the $2 \mathrm{nd}-1$ st century $\mathrm{BC}$, which suggests that their origin, beside other pendant types, lies in the north-Pontic region. In the 1st century BC, these pendants are present with the late Scythians and the Sarmatians from the north and north-west of the Black Sea, but also in the Geto-Dacian and Germanic milieu (the Poieneşti-Lucăşeuca culture).

Once with the 1st century $\mathrm{AD}$, the number of the bucket-shaped pendants increases significantly in the late 
Scythian, Sarmatian, Geto-Dacian environments but also in the cemeteries of the towns and settlements from the north-Pontic area. Still in this period, they start to be recorded in the Przeworsk culture area, as well.

Subsequent to the analysis of bucket-shaped pendant finds from the Sarmatian environment, it was concluded they were not extensively used by the Sarmatians, like in the case of other pendant types. The author notes that the majority of bucket-shaped pendants from the Sarmatian environment of the north and north-west Pontic area come from graves dating to the chronological interval comprised between mid 1st century $\mathrm{AD}$ - early/first decades of the 2nd century AD. Furthermore, these artefacts are rare in second half of the 2nd century - first half of the 3rd century AD Sarmatian graves and are missing from the second stage of the late Sarmatian period (the second half of the 3rd century - 4th century AD).

Following the analysis of the Sarmatian funerary features of the Great Hungarian Plain in which bucket-shaped pendants were discovered, it is concluded that the custom of wearing such pendants by women and children was carried to this area in the second half of the 1st century AD by the first groups of Sarmatians that settled the region. Last but not least, it was noted that in the Sarmatian environment of this geographical area these artefacts were used, to a more or less extent, on the entire duration of their inhabitancy of this area.

In the end it is concluded that the massive use of bucket-shaped pendants in the 2nd - 4th century AD in various cultural environments of the area comprised between the north of the Black Sea and Central Europe evidences they became "supranational" artefacts, being produced and used by different populations from this geographical area.

CUVINTE CHEIE: pandantive-căldărușă, amulete, morminte, sarmați, spațiul nord şi nord-vest pontic, Marea Câmpie Ungară, geto-daci, sciți târzii, germanici, Przeworsk, Barbaricum

KEYWORDS: bucket-shaped pendants, amulets, graves, the Sarmatians, the north and north-west Pontic area, the Great Hungarian Plain, the Geto-Dacians, late Scythian, the Germans, Przeworsk, the Barbaricum.

Similarly to other cultural environments of the Antiquity, pendants were also frequently used in the Sarmatae world. These are jewellery items made in gold, silver, bronze, iron yet also in bone, stone, alabaster, chalkstone, soapstone, glass and amber. They are of different forms and types and play an important role among the Sarmatae grave goods. Pendants are commonly small items, part of sets composed of several jewellery objects. In certain cases, these were the central piece other times they were worn independently. Some of the pendants that the Sarmatae used also fulfilled an apotropaic function.

The bucket-shaped pendants ${ }^{1}$ discovered in the Sarmatae environment are made of iron, bronze, silver or gold sheet, are in an elongated or short cylindrical shape, have a flat base and are provided with a small attachment handle. Occasionally, in Sarmatian and Late Scythian burials from Crimea as well as the cemeteries of certain towns and settlements from the north of the Black Sea, also emerge exemplars formed of two or even three buckets $^{2}$. In a 1st century AD grave from the Late Scythian cemetery of Neapolis (Crimea) is known a quadruple bronze exemplar ${ }^{3}$. Often, double bucket-shaped pendants made in gold are decorated in the filigree technique, alike the common specimens in the same metal from the north and north-west of the Black Sea ${ }^{4}$.

These objects were mainly worn in chains around the neck or by the wrist beside other pendants, beads or amulets ${ }^{5}$, often forming necklaces or bracelets. Evidence to this effect is the fact that in many graves, including from the Sarmatae milieu, such pendants were discovered in the neck area of the deceased. Nevertheless, it is worth mention that in some cases, these were worn by the belt/strap. Their find in the pelvis or thighs area further confirms such hypothesis ${ }^{6}$.

\footnotetext{
This study is a revised, supplemented and much extended version of the paper published in Romanian in volume Miscellanea Historica et Archaeologica in honorem Professoris Ionel Cândea septuagenarii: 43-75. Bucharest-Brăila: The Romanian Academy Publishing House \& Istros Press, 2019

2 Cf. Mordvintseva and Trejster 2007, vol. I, 96-97 with references. These belong to types $\mathbf{J}$ and $\mathbf{K}$ in I. Beilke-Voigt's typology of bucket-shaped pendants (Beilke-Voigt1998, 53, 55, Fig. 58).

3 Cf. Symonovich 1983, 55, 99, P1. XLV/6; Dashevskaya 1991, 38, P1. 70/37.

4 Decorating pendants in the filigree technique is a tradition origination in the late Hellenistic period (Mordvintseva and Trejster 2007, vol. I, 97).

5 Bârcă 2006, 133.

6 For how these pendants were worn see Beilke-Voigt 1998, 79-93, Fig. 94-100.
} 
In some cases, on the internal walls of certain bucket-shaped pendants discovered in the Sarmatian environment of the north-Pontic area still survive the dry remains of their content ${ }^{7}$. For instance, inside a bucket pendant from the grave in the Zolotaya Balka cemetery still preserved wool remains ${ }^{8}$, while in one of the pendants from the Sarmatae grave (T 2/41 Gr 1) in the Chertovitsk I cemetery there still existed pieces of twisted fabric ${ }^{10}$. In one of the pendants from the Sarmatae grave (T 7 Gr 4) at Bădragii Vechi (the Prut-Dniester interfluve) still survived the remains of a white matter (substance) ${ }^{11}$. A yellow substance also had inside one of the pendants from the richly furnished graves of the Sokolova Mogila barrow ${ }^{12}$ (Lower Bug). The dry remains of the content still survived on the sides of golden pendant composed of two soldered buckets from the same grave ${ }^{13}$.

It was concluded based on these aspects that the role of the bucket pendants was to store various medical organic protective remedies (mineral, vegetal, animal), and since they could be opened, such substances could be replaced according to necessity ${ }^{14}$.

Since occasionally, bucket-shaped pendants were discovered together with items of a cult-magical function, it was concluded these may be deemed amulet-pendants fulfilling an apotropaic role ${ }^{15}$. Also, it is believed that inside the buckets, various incantations were preserved (spells) ${ }^{16}$.

Either in gold, silver, bronze or iron, the bucket-shaped pendants are not, as we shall see below, frequently present in the Sarmatae graves from the north-Pontic territories, alike other pendant types. They were not extensively used ${ }^{17}$ either in the Sarmatian setting of the Great Hungarian Plain, even though their find encompasses this entire geographical area ${ }^{18}$.

On the western territory of Romania, among recent finds of bucket-shaped pendants also count those in iron from graves $9^{19}$ (Fig. 1/1) and $13^{20}$ (Fig. 1/2) in the Sarmatae cemetery of Hunedoara Timișană (Șagu commune, Arad county), located south the Lower Mureș ${ }^{21}$.

On the basis of grave goods, it was concluded that $\mathrm{Gr} 9^{22}$ dates to the chronological frame comprised between late 2nd century $\mathrm{AD}$ and first half of the 3 rd century $\mathrm{AD}^{23}$, while Gr $13^{24}$ sometime over the course of the first three quarters of the 3rd century $\mathrm{AD}^{25}$.

\footnotetext{
See in this respect Kovpanenko 1986, 95, 97, Fig. 100/1-2, 101/1, 3.

8 Vyaz'mitina 1972, 22, Fig. 7/6.

9 The cemetery lies nearby the Voronezh river, a left tributary of the Don.

10 Medvedev 1990, 90.

1 Bârcă 2006, 133, 277

2 Kovpanenko 1986, 97, Fig. 101/1.

13 Kovpanenko 1986, 95, Fig. 100/2, 101/3.

14 Rustoiu 2019, 170.

15 Symonovich 1983, 99; Bârcă 2006, 133. See the more recent discussion in Rustoiu 2019, 169-170.

16 Vyaz'mitina 1972, 153.

17 For the finds in the Sarmatae environment of the Great Hungarian Plain see Ishtvanovich and Kul'char 2017, 51-61, with complete references; Bârcă 2018, 37-63.

18 One must though mention these small artefacts are very fragile, often the small fragments that could result from such pieces being not identified either during the archaeological excavations or when their results are published, which explains to a certain extent the not very large number of bucket-shaped pendants. Also, it must be underlined that, very likely, many such pieces were yielded by more recent rescue archaeological investigations, still unpublished.

19 The pendant in Gr 9 is made of iron sheet, is cylindrical in shape and has a flat base. The attachment handle did not survive. Height $-1.2 \mathrm{~cm}$, diameter $-1.2 \mathrm{~cm}$. It was discovered on the northern side of the gravepit, nearby teeth and a series of beads (Bârcă 2014, 155, Fig. 26/5; 26/1.5; Bârcă 2018, 39, Fig. 2/1.5; 2/5).

20 The bucket pendant in Gr 13 was discovered among beads at ca. $0.7 \mathrm{~m}$ from the skull bones and teeth. It is made of iron sheet and is cylindrical, with flat base. The attachment handle did not survive. Height $-1.35 \mathrm{~cm}$, diameter $-1.3 \mathrm{~cm}$ (Bârcă 2014,157-158, Fig. 33/2; 33/1.2; Bârcă 2018, 39, Fig. 6/1.2; 6/2).

$21 \quad$ For further details and information regarding this cemetery see Bârcă 2014.

22 Among the grave goods also counts a "Sarmatian" bronze brooch, the version with external chord and vertical catchplate without headknob, a silver pendant in the shape of a half-moon, 201 beads, mainly in glass, an iron pin and a wheel-thrown cup (Cf. Bârcă 2014, 155-156, Pl. 26-29; 59-61). For the analysis of brooches of the type see Cociș and Bârcă 2014, 189-214; Bârcă 2014, 115-117; Cociş and Bârcă 2020, 137-180. Based on the grave goods and gravepit size it was concluded the deceased was likely a subadult /female (age could not be established).

23 Bârcă 2014, 156.

24 Beside the bucket-shaped pendant, the grave goods of Gr 13 also contained 56 beads, of which 30 in amber, to which add a cup and wheel-thrown bowl, discovered fragmentary. Both vessels were found set one close to another, on the southern side of the gravepit, in the feet area (Cf. Bârcă 2014, 157-158, Pl. 33-34; 65; 78/3). Based on the grave goods and gravepit sizes it was concluded the deceased was a child. Following the analysis of the bone remains, it was noted the infant was aged 4-5 years (Radu and Szeredai 2014, 81, 82).

25 Bârcă 2014, 158.
} 
Among the recently discovered items in the Sarmatae milieu of the Great Hungarian Plain count the iron specimens in Gr 36 at Abony-Kisbalaton-dül 'b $^{26}$ (Fig. 4/4) and Gr 138 at Óföldeák-Ürmös II ${ }^{27}$, those in silver (4 specimens) in Gr 11 at Orosházi-tanyák $k^{28}$ (Fig. 4/2), the silver exemplars (1 piece) and bronze (1 piece) in a grave from DerecskeDarabos-dülón ${ }^{29}$, or the silver exemplars (9 specimens) and iron (11 specimens) from a female burial at Kálló ${ }^{30}$ (Fig. 5). Grave 11 at Orosházi-tanyák is dated to AD 180-230 that of Derecske-Darabos-dülö in the 2nd century AD, while the grave of Kálló to the end of the 1st century - early 2nd century AD. To the second half of the 4th century - first half of the 5th century AD is dated the cemetery of Óföldeák-Ürmös II ${ }^{31}$.

To these add those recently published from Gr 39 (one in gold, six in silver and two in bronze), Gr 41 (two in silver and one in bronze), Gr 60 (bronze), Gr 71 (bronze), Gr 82 (silver), Gr 83 (bronze), Gr 93 (bronze), Gr 117 (bronze), Gr 140 (bronze), Gr 149 (silver) and Gr 235 (bronze) of Nyíregyháza-Felsösima ${ }^{32}$ (Fig. 4/13). These graves which contain bucket-shaped pendants are dated, depending on their grave goods, to certain chronological frames over the course of the 2 nd -3 rd century $\mathrm{AD}^{33}$.

In the north-west of the Black Sea a bronze pendant has been recently discovered in grave 3 at Medeleni ${ }^{34}$ (Fig. 2/6) (the Prut-Dniester interfluve). The grave was found beside other four in the vicinity of a square ditched enclosure provided with access on the southern side ${ }^{35}$. The grave goods in these graves, including $\mathrm{Gr} 3^{36}$, are indicative in our view, of a dating sometime to the chronological interval comprised between the last quarter of the 1 st century AD and the first decades of the 2nd century AD.

In the Sarmatae environment, bucket pendants come mainly from infant and female graves ${ }^{37}$. Even more, it is noted these are found in both richly or more poorly furnished graves, which is also valid for the north and north-west Pontic Sarmatae environment. This evidences, in our view, that bucket pendants were worn both the wealthier representatives of the Sarmatae society as well as by the commoners, those in gold emphasizing the special status of their bearers.

The discovered bucket pendants in the Sarmatae milieu are made in iron, bronze, silver or gold sheet, are in a cylindrical shape, have a flat base and are provided with a small attachment handle. In some Sarmatae graves are also found double exemplars formed of two buckets.

Most of these artefacts from the Sarmatae graves in the north-Pontic area are notable by their common features and belong to type $\mathbf{A}$ in I. Beilke-Voigt's typology ${ }^{38}$. In the type, two variants may be distinguished. The first is represented by exemplars with cylindrical short body, their height and diameter being similar or close in sizes, yet there are also found exemplars with a slightly larger height compared to the diameter and exemplars whose diameter is somewhat larger than the height. The pendants in the second variation have an elongated cylindrical body and a height up to twice larger than the diameter.

Among the bucket pendant finds in the first variation count those in iron from Gr 5 at Ostrivec-Vertebi ${ }^{39}$ ( 1 piece), T 7 Gr 4 at Bădragii Vechi ${ }^{40}$ (2 pieces) (Fig. 1/4-5), T 1 Gr 5 at Zîrneşti ${ }^{41}$ (1 piece) (Fig. 1/3), T 4 at Kholmskoe ${ }^{42}$ (2 pieces) (Fig. 2/2-3), T 1 Gr 8 at Pisarevka ${ }^{43}$ (7 pieces) (Fig. 2/7, 11-16), Gr 3 in the Sokolova Mogila

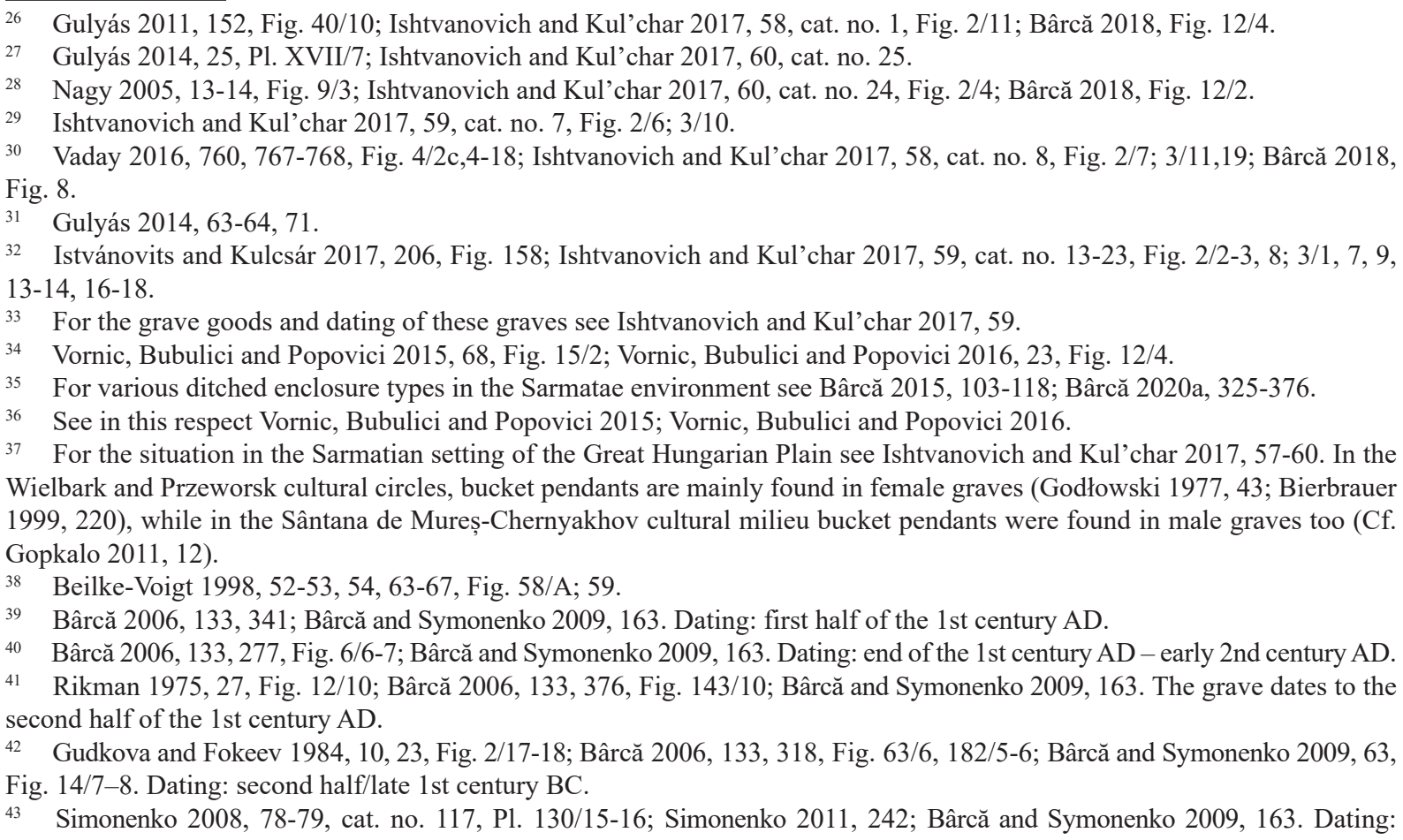


barrow $^{44}$ (2 pieces) (Fig. 3/2-3) or T 2 Gr 1 at Chuguno-Krepinka ${ }^{45}(1$ piece) (Fig. 2/17). To these add those in bronze from T 3 Gr 3 Podojma $^{46}$ (1 piece) (Fig. 2/4), Gr 3 at Medeleni ${ }^{47}$ (1 piece) (Fig. 2/6) and T 2 Gr 9 at PrăjeniTarnă ${ }^{48}$ (3 pieces) (Fig. 3/6-8), as well as those made of gold from T 3 Gr 3 at Mikhajlovka ${ }^{49}$ (Fig. 2/19-20), Tsvetna $^{50}$ (1 piece) (Fig. 2/21-22) and T 3 at Kazanskaya ${ }^{51}$ (2 pieces) (Fig. 1/6).

The graves with bucket pendants in the first variation date mainly to the Middle Sarmatian Period (1st century first half of the 2nd century AD) ${ }^{52}$, the largest part dating to certain chronological spans of the second half of the 1 st century - early/first decades of the 2nd century AD. Exceptions are T 4 at Kholmskoe dated to the second half/ end of the 1st century BC (the Early Sarmatian Period), yet also T 3 Gr 3 at Podojma, dated to the second half of the 2nd century - early 3rd century AD (first phase of the Late Sarmatian Period). Another note worth making is that six of the graves with bucket pendants belonging to this variation come from the Prut-Dniester interfluve (Ostrivec-Vertebi, Bădragii Vechi, Medeleni, Zîrnești, Kholmskoe, Mikajlovka), two from the area left of the Middle Dniester (Pisarevka, Podojma) and one each from territories to the right of the Prut (Prăjeni-Țarnă), Lower Bug (the Sokolova Mogila barrow), Middle Dnieper (Tsvetna) and the Don-Nipru interfluve (Chuguno-Krepinka). The grave in T 3 at Kazanskaya belongs to the "Zolotoe kladbishche" cemetery, located on the right bank of the Kuban river (north-east of the Black Sea).

The bucket pendants in the second variation are in iron, bronze and gold. Iron exemplars were discovered in $\mathrm{T} 4$ at Kholmskoe $^{53}$ (1 piece) (Fig. 2/1), T 1 Gr 2 at Lenkovtsy ${ }^{54}$ (2 pieces) (Fig. 2/5), T 1 Gr 8 at Pisarevka ${ }^{55}$ (3 pieces) (Fig. 2/8-10), bronze-made in a destroyed barrow grave at Zaprud' $e^{56}(1$ piece) (Fig. 1/7) and T 2/41 Gr 1 in the Chertovitsk I cemetery ${ }^{57}$ (1 piece) (Fig. 1/8). In what the golden specimens are concerned, these come from T 17 Gr 1 in the Vysochino VII cemetery ${ }^{58}$ (1 piece) (Fig. 1/11) and T 6/11 gr 1 in the Chertovitsk I cemetery ${ }^{59}$ (1 piece).

Except for the grave in T 4 at Kholmskoe, dated by late the Early Sarmatian Period and T 17 Gr 1 in the Vysochino VII cemetery, dated by late 2nd century - first half of the 3rd century AD, the remaining mentioned graves span the time interval comprised between mid 1st century AD and early 2nd century AD. Two of the finds of bucketpendants belonging to the second version come from the Prut-Dniester interfluve (Lencovtsy, Kholmskoe), and one each from the left of the Middle Dniester (Pisarevka) and the right of the Middle Dnieper (Zaprud'e). A single find comes from the left of the Don mouths (Vysochino VII), and other two from the left of the Middle Don (Chertovitsk I).

To these add several double exemplars formed of two buckets. The discovered items are made in bronze, silver and gold and belong to the first variation of type $\mathbf{J}$ in I. Beilke-Voigt's typology ${ }^{60}$.

second half of the 1 st century AD.

44 Kovpanenko 1986, 96, Fig. 100/1. 3; 101/1-2. Dating: the second half of the 1st century AD (possibly the third quarter or even its last third).

45 Simonenko 2008, 65-66, cat. no. 70, Pl. 65/11. Dating: first half of the 2nd century AD (likely towards the end of this chronological interval). See also Bârcă 2020, 84.

46 Bubulich and Khakheu 2002, 122, 146, Fig. 6/A3. Dating: the second half of the 2nd century - early 3rd century AD.

47 Vornic, Bubulici and Popovici 2015, 68, Fig. 15/2; Vornic, Bubulici and Popovici 2016, 23, Fig. 12/4. Dating: last quarter of the 1 st century AD - first decades of the 2 nd century AD.

48 Ursulescu et al. 2021, 172, Pl. XVII/3-5, XVIII/2-4. Dating: end of the 1st century - early 2nd century AD.

49 Subbotin, Dzigovskij and Ostroverkhov 1998, 21, Fig. 16/5; Dzygovs'kyj 2000, Fig. 43/3; Bârcă 2006, 133, 329, Fig. 75/5, 182/7; Simonenko 2008, 77, cat. no. 107, P1. 119/5; Bârcă and Symonenko 2009, 163, Fig. 60/3; Mordvintseva and Trejster 2007, vol. I, 96, vol. II, 45, cat. no. A129.2. Dating: the second half of the 1st century AD - early 2nd century AD.

50 Simonenko 2008, 69, cat. no. 87, Pl. 81/5; Mordvintseva and Trejster 2007, vol. I, 96, vol. II, 136, cat. no. B46. Dating: the second half - late 1 st century AD.

${ }_{51}$ Gushchina and Zasetskaya 1994, 42, cat. no. 20, Pl. 2/20; Marčenko and Limberis 2008, 346, cat. no. 34. Dating: the second half of the 1st century AD - early 2nd century AD.

52 For all chronologies suggested for the Sarmatian world from the north and north-west of the Black Sea see Symonenko 1999 , 5, 9, 12, 27, 34; Simonenko 2004, 134-173; Simonenko 2011, 151-157; Bârcă 2006, 31-36; Bârcă and Symonenko 2009, 37-40.

53 Gudkova and Fokeev 1984, 10, 23, Fig. 2/16; Bârcă 2006, 133, 318, Fig. 63/6, 182/4; Bârcă and Symonenko 2009, 63, Fig. 14/6. Dating: the second half/late 1st century BC).

54 Bârcă 2006, 133, 323, Fig. 70/2; Bârcă and Symonenko 2009, 163. Fig. 60/7. Dating: the second half of the 1st century AD.

55 Simonenko 2008, 78-79, cat. no. 117, Pl. 130/15-16; Simonenko 2011, 242; Bârcă and Symonenko 2009, 163. Dating: the second half of the 1 st century AD.

56 Romanyuk and Symonenko, 2001, 23, Fig. 1/5; Simonenko 2008, 68-69, cat. no. 85, Pl. 76/23. Dating: 1st century AD, most likely its second half.

57 Medvedev 1990, 33, 90, Fig. 9/10. Dating: second half of the 1st century AD - early 2nd century AD (?).

58 Bespalyj 1990, 213, Fig. 1/14. Dating: late 2nd century - first half of the 3rd century AD.

59 Medvedev 1990, 41, 90, Fig. 12/13. Dating: second half of the 1st century AD - early 2nd century AD (?).

60 Beilke-Voigt 1998, 52-53, 55, 69, Fig. 58/J. 
The bronze exemplars come from T 5 Gr 1 at Ust'-Kamenka ${ }^{61}$ (1 piece) (Fig. 1/15), Lipovets ${ }^{62}$ (1 piece) (Fig. 2/18), T 11 Gr 1 in the Chertovitsk II cemetery ${ }^{63}$ (1 piece) (Fig. 1/14) and T 2/41 Gr 1 in the Chertovitsk I cemetery ${ }^{64}(2$ pieces) (Fig. 1/9-10), while those in silver from T 17 Gr 1 in the Vysochino VII cemetery ${ }^{65}$ (2 pieces) (Fig. 1/12-13). Such pendants made in gold were discovered in the Sokolova Mogila barrow ${ }^{66}$ (3 pieces) (Fig. 3/1), T 19 Gr 1 in the barrow cemetery of Karshinskij ${ }^{67}$ ( 1 piece) and T 38 at Ust'-Labinsk ${ }^{68}$ (1 piece). All mentioned graves, except for T 17 Gr 1 in the Vysochino VII cemetery date to the Middle Sarmatian Period and frame certain chronological intervals comprised between mid 1st century AD and first half of the 2nd century AD. From the point of view of the geographical location of said finds, they lack from the Prut-Dniester and Dnieper-Don interfluves, with only two finds in the territory between the Dnieper and the Bug (Lipovets, Ust'-Kamenka). In the north-west Pontic area, such artefacts come from the Sokolova Mogila barrow (right to the Lower Bug). A single find of such pendants come from the north-east of the Black Sea (Ust'-Labinsk), and two each from the territories left of the Don mouths (Karshinskij, Vysochino VII) and Middle Don (Chertovitsk I, Chertovitsk II).

Singular for the north-Pontic Sarmatian environment is the golden pendant with body decorated with horizontal ribs in relief from Gr 3 in the Sokolova Mogila barrow ${ }^{69}$. It belongs to the first variation of the $\mathbf{H}$ type in above typology ${ }^{70}$.

Similarly to the north-Pontic Sarmatian environment, in that of the Great Hungarian Plain most bucket pendants belong to type $\mathbf{A}$ in I. Beilke-Voigt's typology ${ }^{71}$, dominant being those in the first variation. Exception make the silver cone-shaped pendants in Gr 11 at Orosházi-tanyák $k^{72}$ (Fig. 4/2) which belong to type $\mathbf{F}^{73}$. Compared to the north-Pontic Sarmatian environment, in that of the Great Hungarian Plain exemplars formed of two buckets are missing.

The items in the first variation from the Sarmatae environment of the Great Hungarian Plain are made in gold, silver, bronze and iron, being much more numerous than those in the second variation ${ }^{74}$. To the first variation also belong the iron specimens from graves 9 (Fig. 1/1) and 3 (Fig. 1/2) in the Hunedoara Timișană cemetery. To this version also belongs the golden specimen from the infant grave at Átány ${ }^{75}$ (Fig. 4/6), dated to the last quarter/end of the 1 st century $\mathrm{AD}$ - early 2 nd century $\mathrm{AD}$, yet also that made in the same metal from Gr 39 at NyíregyházaFelsösima ${ }^{76}$ (Fig. 4/13), dated to the second half of the 2nd century $\mathrm{AD}^{77}$.

The bucket pendants in the second variation are in bronze and iron and mainly come from Early Sarmatian Period graves from the Great Hungarian Plain ${ }^{78}$, some dating to the late 1st century - early 2nd century AD (AlsónémediFaluréti domb $^{79}$, Kálló ${ }^{80}$ (Fig. 5), Endrőd-Szujókereszt ${ }^{81}$ (Fig. 4/3)).

${ }_{61}$ Makhno 1961, Fig. 2/12; Arkheologiya SSSR 1989, Pl. 82/56; Kostenko 1993, Fig. 28/19; Simonenko 2008, 63, cat. no. 54, P1. 42/3h; Simonenko 2011, 187. Dating: the second half of the 1st century - early 2nd century AD.

${ }_{62}$ Simonenko 2008,68, cat. no. 82, Pl. 72/2g; Bârcă and Symonenko 2009, 163. Dating: the second half of the 1st century first decades of the 2 nd century AD.

${ }_{63}$ Medvedev 1990, 68, 90, Fig. 27/7. Dating: the second half of the 1st century AD.

${ }_{64}$ Medvedev 1990, 33, 90, Fig. 9/8-9. Dating: the second half of the 1st century AD - early 2nd century AD (?).

${ }_{65}$ Bespalyj 1990, 213, Fig. 1/3. Dating: late 2nd century - first hal of the 3rd century AD.

66 Kovpanenko 1986, 95, 98, Fig. 100/2, 101/3; Mordvintseva and Trejster 2007, vol. I, 96, vol. II, 80, cat. no. A250.12.

${ }_{67}$ Mordvintseva and Trejster 2007, vol. I, 96, vol. II, 38, cat. no. A105.1. Dating: 1st century AD.

68 Gushchina and Zasetskaya 1994, 68, cat. no. 417, 5, P1. 45/417, 5. Dating: first half of the 2nd century AD.

69 Kovpanenko 1986, 97, Fig. 103; 104/3; Mordvintseva and Trejster 2007, I, 96, II, 80, cat. no. A250.11.

70 Beilke-Voigt 1998, 52-53, 55, 68-69, Fig. 58/H; 60.

1 Beilke-Voigt 1998, 52-53, 54, 63-67, Fig. 58/A; 59.

72 Nagy 2005, 13-14, Fig. 9/3; Ishtvanovich and Kul'char 2017, 60, cat. no. 24, Fig. 2/4; Bârcă 2018, Fig. $12 / 2$.

73 Beilke-Voigt 1998, 55, Fig. 58/F.

74 Cf. Ishtvanovich and Kul'char 2017, 55; Bârcă 2018, 40.

75 Párducz 1941, 56, P1. XXIX/56.

76 Istvánovits and Kulcsár 2017, 206, Fig. 158.

77 Ishtvanovich and Kul'char 2017, 59.

78 In the current state of research, it is certain the first Sarmatae arrived and settled the Great Hungarian Plain once with the second half of the 1st century AD (Cf. Bârcă 2014, 35-69). We believe this places the start of the Early Sarmatian Period in the area in the 50'ies AD. According to the archaeological and historical facts, the end of the first phase of the Early Sarmatian Period from the Great Hungarian Plain may be established by the end of the political and military events of the early 2 nd century AD. Regarding the end of the second phase, it may be placed towards the end of the Marcomannic Wars, when in the area emerge new Sarmatae groups from the north-west Pontic area, who carry a series of elements specific to the Middle and Late Sarmatian Periods from the north-Pontic area, including in funerary rites and rituals. Therefore, the first phase of the early Sarmatian Period from the Great Hungarian Plain corresponds to the last part of phase B1 - phase B2a in the Central-European chronology, and the second to phase B2b - first decades of stage C1a (B2/C1). For the chronology of the Sarmatian culture in the Great Hungarian Plain see Bârcă 2014, 31-32.

79 Korek 1980, Fig. 13/2.

80 Vaday 2016, 760, Fig. 4/9-18.

81 Vaday and Szőke 1983, 82, Fig. 6/2. 
The bucket-shaped pendants, either similar or close to those discovered in the Sarmatian graves, yet belonging to other types in I. Beilke-Voigt's typology ${ }^{82}$ are also documented in the Geto-Dacian ${ }^{83}$, Late Scythian ${ }^{84}$ (Fig. 7/1, 6-13) and the Poieneşti-Lucăşeuca culture environments ${ }^{85}$. These artefacts are also frequent in the Germanic world, mainly in the Przeworsk culture $\operatorname{area}^{86}$. In the Zemplin cemetery (Slovakia) such pendants come both from Germanic (Przeworsk) and Dacian graves ${ }^{87}$ (Fig. 6/1-16). Such pendants are also found in the cemeteries of the towns and settlements from the north-Pontic area ${ }^{88}$, yet they are also known in territories west of the Black Sea, like those in the grave from the Roshova Dragana barrow at Chatalk ${ }^{89}$. These artefacts are not missing either from the cultural environments of the 2 nd -4 th century from the area east ${ }^{90}$ (Cf. Fig. 7/17-20) and south of the Carpathians $^{91}$ (Cf. Fig. 7/14-16), Transcarpathia ${ }^{92}$ (Fig. 7/21-28), as well as those from the territory of Crimea ${ }^{93}$ (Fig. 7/1, 7-13), yet also the entire area of the Sântana de Mureș-Chernyakhov culture ${ }^{94}$. Such iron and filigree silver pendants were discovered in graves from cemeteries on the territory of Roman Dacia (Soporu de Câmpie ${ }^{95}$, Obreja $^{96}$, Locusteni ${ }^{97}$, Fărcașele ${ }^{98}$, Sighișoara-Dealul Viilor ${ }^{99}$ ), but are also known from non-funerary contexts

\footnotetext{
$82 \quad$ Beilke-Voigt 1998, 52-53, Fig. 58/A; 59.

83 Vulpe and Vulpe 1933, 329, Fig. 109/25-27; Vulpe 1976, 198, 208, Fig. 5/10, 6/24; Berciu 1981, 106, Pl. 91/4-5; Berciu
} 1983, 34, 35, Fig. 2/1-3; Ursachi 1986, 112-115, 121, Pl. XVII/5-10, XXI/4-5, XXIII/4-5; Ursachi 1995, 244, Pl. 359/5-10, 361/4-5, 362/4-5; Căpitanu 1989, 103, Fig. 11/16-19; Rustoiu 1996, 125, Fig. 86/41-47; Crişan 2000, 138, Pl. 111/12; Crişan 2000a, Fig. 4/1; Teodor 2005, 131-132, Fig. 2/10; Sîrbu et al. 2007, 19, 20, 25-26, 33, 40, 41, 64, 67, 68, 70, 76, 78-79, Fig. $34 / 1-2,36 / 7,37 / 9,38 / 10,13-14,69$.

84 Vyaz'mitina 1972, 22, 44, 50, 56, 153-154, Fig. 7/6, 17/7, 21/10, 25/3, 5; Symonovich 1983, 99, P1. XLV/6-13; Arkheologiya SSSR 1989, P1. 51/20, 45-46; Dashevskaya 1991, 38, Pl. 70/33-34, 37; Vysotskaya 1994, P1. 9/13, 10/25, 12/58, 15/1, 24, 19/23, 28, 23/30, 31/44-45, 40/20; Zajtsev 1997, Fig. 3/6, 12; Stoyanova 2004, 297; Puzdrovskij 2007, Pl. 15/8; Fig. 57/11, 58/6, 115/4, 144/20; Mordvintseva and Trejster 2007, vol. I, 96, 97; Trufanov 2009, 231, Fig. 65/1-2, 5-6, 9-10, 17, 20; Puzdrovskij and Trufanov 2016, 45, 47, 92, Fig. 81/2-3, 85/3-4, 14, 174/1, 177/4.

85 Smirnova 1981, 195, 204, Fig. 3/5; Babeş 1993, 113, Pl. 47/2g.

86 Cf. Bichir 1973, 119 with complete bibliography; Godłowski 1968, Fig. 1/32, 3/8, 5/20; Godłowski 1970, Pl. I/32, II/9, III/25, IV/10, V/14, VII/22, IX/17, XII/14, XX/21, XXII; Godłowski 1992, Fig. 12/10, 13/17, 18/18, 22/13; Godłowski and Wichman 1998, Pl. III/7-8, LXXII/2, XCII/17; Szydłowski 1964, Fig. 44/2, 101/8, 120, 124/2, 6; Szydłowski 1974, Pl. CII/c-e, i, CLXXX/h-o; Kaczanowski 1980, 179-180; Kaczanowski 1987, Pl. II/10, 32, VI/8; Tempelmann-Mączyńska 1989, map 13; Olędzki 1999, Fig. 2/6, 19, 3/3-4, 8-9, 19/1-12; Droberjar 2002, 377, no. 23, 25-26; Szela 2007, 286, Fig. 1/9; Tejral 1999, Fig. 25/1-3; Tejral 2011, Fig. 26/22; Madyda-Legutko, Rodzińska-Nowak and Zagórska-Telega 2011, Pl. LXXVII/5, CXXII/3-5, 12, 14, 17, CXXXII/1, 7, CXXXV/1, CXXXVI/3, CCCL/1, CCCLI/4, CCCLIV/4, CCCLX/11-12, CDXVIII.

87 Budinský-Krička and Lamiová-Schmiedlová 1990, 294, Pl. III/9-20, VI/3-4, 8-9, XVI/43, XX/11, 25.

88 Cf. Pyatysheva 1956, 60, Fig. 19; Shelov 1961, 78; Shelov 1970, 146; Arsen'eva 1977, Pl. XXIX/2, XXXI/2; Vyaz'mitina 1972, 154-155; Ruxer and Kubszak 1972, 271, Pl. LXX/1-3; Alekseeva 1982, 25, type 24-25; Korpusova 1983, 72, 102, 111, 112, Pl. XI/2, 18, XXII/15; Kazanskij 2006, 29, Fig. 3/9; Mordvintseva and Trejster 2007, vol. I, 96-97.

89 Buyukliev 1986, 67, 106, no. 49, P1. 4.

90 Bichir 1973, 119, Pl. CLXIV/7-10, CLXXXII/13-14; Căpitanu 1975, 64, 65, 67, 75, 85, 90, Fig. 13/4-11; Căpitanu 1976, 161, 163, 167, 174, 179, 181; Ioniţă1977, R50b/9; Ioniţă 1982, Fig. 16/8; Babeş, Miriţoiu, Istrate and Coman 1980, 39, 44, Fig. 3/1; Palade 1985, Fig. 9/6; Palade 1986, R74/3-5, R77/6, R86/1, R87/4; Rafalovich1986, p. 88, P1. XLV/1-10; Ioniţă and Ursachi 1988, 11, 12, 26, 33, 35, 37, 38, 39, 40, 43, 49, 50, 65, 93, Fig. 19/1, 20/1, 28/1, 33/6, 34/9, 35/9, 36/23, 30, 37/48, 38/177, 39/32, 41/15, 44/69, 46/40, 51/22, 61/1-2; Ignat 1980, 64, Fig. 2/5-6; Ignat 1999, 55; Vornic 2006, 182, 206; Șovan 2009, 162, 210, 211-213, tab. 5, Pl. 5/5-9, 35D/3, 54B/2-3, 81D/20, 108A/1, 130B/6, 165/153-154, 194B/3, 220/2, 253/27; Spânu 2019, 52, 54, 58, 69, Fig. 12/2, 13/12-14, Pl. 5/55.8, 8/71.6, 11/130.2, 15/230.6, 22/327.6, 25/360.2, 26/437, 29/538.3$5,38 / 720.5,39 / 741.7,48 / 1000.10-14,59 / 1352.1-5$. In the 2nd - 3rd century cemetery of Poienești (Vaslui county), bucket pendants were discovered according to Daniel Spânu, in 19 graves, of both cremation and inhumation. Out of these, 10 are in bronze and 20 in iron, to which adds a silver exemplar with granulated and filigree decoration).

${ }_{91}$ Diaconu 1965, 94-95, 286, Pl. CXXIV/5, CXXXVI/18; Diaconu 1970, 16, Fig. 15/4, 7; Diaconu1986, Fig. 2/3; Bichir 1984, 53-54, Pl. L/16-18.

92 Kotigoroshko 1987, 187-188, Fig. 7/1-15, 25-26, 29.

93 Cf. Kazanskij 2006, 29, Fig. 3/10-11; Stoyanova 2016, 130-132, Fig. 3/8-16, with complete references; Khrapunov 2002 , 47, Fig. 104/3-4; Khrapunov 2013, 43, Fig. 35/6, 8-10.

94 Magomedov 2001, 70, Fig. 74/1-6; Gopkalo 2008, 63-65, with complete references. For finds in the Sântana de MureşChernyakhov environment from the area east and south of the Carpathians see also certain bibliographical references from previous notes.

95 Protase 1976, 66, 68, note 123, P1. XXX/2.

96 Protase 2002, Pl. LVI/M.c.

${ }_{97}$ Popilian 1980, 34, 37, 38, 42, 92, 93, Pl. XXI/M144, 2, XXII/M162, 3-5, XXIV/M177, 5-10, XXVII/M194, 6-7. Opreanu 1998, 99, Fig. 15. The 17 bucket-pendants in the Locusteni cemetery are made of filigree silver.

98 Bichir 1973, 119; Protase 1976, 68.

99 Spânu 2014-2015,43, Fig. 2/195b. 
within the province territory ${ }^{100}$. Such pendants are present in the Barbarian environment west of Dacia (Suplacu de Barcău ${ }^{101}$ as well (Fig. 7/3)). In the case of filigree silver specimens from the Locusteni cemetery it is worth mentioning these come from graves dated to the first half of the 2 nd century ${ }^{102}$ and belong to type $\mathbf{M}$ in I. BeilkeVoigt's typology ${ }^{103}$. The item of Suplacu de Barcău is of gold and has the body decorated in the filigree technique, coming from a 3rd century context ${ }^{104}$.

As it may be noted, bucket pendants were broadly diffused in various cultural milieus from the Roman imperial period, which over the course of time raised increased interest for their study. Nevertheless, it must be noted that although various scholars attempted to identify their origin, the time when they emerge in certain cultural environments and their diffusion paths, it is increasingly obvious today that some of these aspects remained unanswered.

\section{$* * *$}

On their shape, it was believed it was spontaneous and sporadic in different regions ${ }^{105}$. For the bucket pendants in the Sântana de Mureș-Chernyakhov environment from the north and north-west of the Black Sea, it was argued they represent the evidence of the arrival in this area of the Germanic tribes and that they are of Gothic origin ${ }^{106}$. It is not excluded that some of these pendants were adopted from the Carpi, then allies of the Goths ${ }^{107}$. A diametrically opposite view was expressed by E. A. Symonovichi, who rejected any connection between the Sântana de MureșChernyakhov finds from the north of the Black Sea and the further westward parallels, considering, based on the presence of these pendants in the north-Pontic area much prior, that these were adopted from the local populace ${ }^{108}$.

Also, it was believed that bucket pendants originate in the Przeworsk culture area, from where they were adopted by the Carpi, Sarmatae etc. ${ }^{109}$. Later, based on finds of such pendants in the pre-Roman Geto-Dacian area it was evidenced that there, they emerged earlier and spread to other ethno-cultural areas ${ }^{110}$. I. Ionuţă believes that pendants in the shape of a bucket are specific only to the Goths and the Dacians ${ }^{111}$ and that iron exemplars from the Free Dacians milieu have correspondences only in Dacian and by no means Sarmatea cremation graves ${ }^{112}$. Based on archaeological facts, yet also the fact that bucket-pendants were used in the 1 st century $\mathrm{BC}$ - first centuries $\mathrm{AD}$ on a spread area in various cultural environments, it was argued these may be deemed "supranational" artefacts ${ }^{113}$.

An interesting hypothesis was expressed by I. A. Bazhan and S. Yu. Kargopol'tsev, who believe these pendants originate in the ancient centres of the north-Pontic area, where they were largely diffused by the boundary between the 1st century BC -1 st century AD, being adopted by the Sarmatae and the Late Scythians ${ }^{14}$ in the first half of the 1st century AD following contacts with the north-Pontic ancient centres. Via the Sarmatae, according to the two scholars, the bucket pendants reached farther to the west, where at their turn were adopted by the bearers of the Poienești-Vârteșcoiu and Przeworsk cultures, and then, via the latter, in the rest of the area inhabited by the Germanic populaces ${ }^{115}$. Following the analyses of features comprising such pendants known at that date in the north of the Black Sea, the two scholars noted their lack in graves from the chronological interval comprised between the end of the 2 nd century AD and first half of the 3 rd century AD. This made them conclude the pendants re-emerge in the east-Carpathian and north-Pontic area following the entry and influence of the Germanic peoples in the C2-C3 phases of the Central-European chronology ${ }^{116}$. Somewhat more recently, M. B. Shchukin concluded that once with establishment process of the Chernyakhov culture, iron bucket pendants and rarely in gold with filigree decoration re-emerge in the north-Pontica area under the cultural impulse of the north-western regions ${ }^{117}$. Furthermore, the

100 Pop 1966, 175-176; Protase 1976, 68.

101 Gindele 2015, 11, Fig. 20.

102 See for the dating of these pendants and of the cemetery Opreanu 1998, 99, 101, 102, 103.

103 Beilke-Voigt 1998, 56, Fig. 58/M.

104 We thank this way too our colleague and friend Robert Gindele for kindly providing us this information.

105 Bazhan and Kargopol'tsev 1989, 163.

106 Blume 1912, 97, 98; Kukharenko 1958, 82; Kropotkin 1978, 156, 157.

107 Bazhan and Kargopol'tsev 1989, 166.

108 Symonovich 1983, 72.

109 Bichir 1973, 119.

110 Cf. Vulpe 1976, 214; Bichir 1984, 54; Ursachi 1986, 121; Rustoiu 1996, 125.

111 Ioniţă 1982, 111.

112 Ioniţă 1982, 66

113 Babeş 1999, 230; Bârcă 2006, 134. See in this respect also Rustoiu 2019, 169.

114 Bazhan and Kargopol'tsev 1989, 164, 169.

115 Bazhan and Kargopol'tsev 1989, 169.

116 Bazhan and Kargopol'tsev 1989, 169.

117 Shchukin 2005, 190. 
author argued these became a characteristic trait of the Chernyakhov culture, although they continued to be used on the entire diagonal the Baltic - Black sea, the Caucasian coast of the Black Sea and the Tsebeldin valley ${ }^{118}$. The archaeological research of the last three decades revealed though graves with such pendants ${ }^{119}$ which date to late 2nd century - first half of the 3rd century AD, thus invalidating the view expressed by I. A. Bazhan and S. Yu. Kargopol'tsev. Their use in this time frame is confirmed by the finds in Sarmatae graves from the left of the Don mouths ${ }^{120}$ (T 17 Gr 1 in the Vysochino VII cemetery) and left the Middle Dniester ${ }^{121}$ (T 3 Gr 3 at Podojma). Notably, in T 17 Gr 1 at Vysochino VII beside the bronze bucket pendant, there are other two double made of silver.

A different view has been recently expressed by I. Khrapunov ${ }^{122}$, who believes there are either two independent traditions for making bucket pendants, Germanic and north-Pontic, or the Germanic population has borrowed this tradition from the north-Pontic area, possibly via the Sarmatae or the northern Thracians (namely, the GetoDacians), in whose inhabitancy area bucket pendants were identified ${ }^{123}$. According to the same scholar, both the Germanic populations as well as those from the north of the Black Sea produced at a certain point such pendants concurrently.

For the Sarmatae milieu of the Great Hungarian Plain, it was argued until recently that bucket pendants were more extensively used in the Early Sarmatian Period, yet also that in the 3rd century AD they ceased to exist, only to reemerge in the late stage of the Late Period (late 4th century - early 5th century AD) ${ }^{124}$. Another view was expressed by M. B. Shchukin, who argued that bucket pendants diffuse in the Sarmatae milieu on the Hungarian territory and the Carpathian Basin and also among the Germanic populaces inhabiting the lower course of the Oder river and upper Elbe as well as the Carpii from the east-Carpathian area in the 2nd century AD, mainly its second half ${ }^{125}$.

Based on the archaeological finds of numerous such pendants over the last decades as well as subsequent to the analysis of the graves in which these were identified, it was noted that in the Sarmatae milieu of the Great Hungarian Plain bucket pendants were used over the course of their entire inhabitancy of this geographical space ${ }^{126}$.

$* * *$

Bucket pendants emerge in the north-Pontic area sometime in the 2nd - 1st century BC, yet no later than the 1st century BC. For instance, from grave 180 in the cemetery of the town of Tanais come two golden bucket pendants with their body decorated with horizontal ribs in relief ${ }^{127}$, yet also two earrings with zoomorphic heads made of the same metal, decorated with pseudo-granulation and pseudo-filigree ${ }^{128}$. The pendants belong to type $\mathbf{H}$, variation I in I. Beilke-Voigt's typology ${ }^{129}$. With respect to the earrings, such types were broadly diffused in the late Hellenistic period ${ }^{130}$. In the north-Pontic territories, earrings in this type come mainly from 2 nd -1 st century BC graves $^{131}$. Such an earring comes from a Sarmatian grave (?) discovered in 1985 at Solontsy, dated to the 2nd -1 st century $\mathrm{BC}$, 1st century $\mathrm{BC}$ or only in the second half of the 1 st century $\mathrm{BC}^{132}$. To the torsion ring of this earring was attached a golden cylindrical pendant provided with attachment handle whose surface was decorated with a filigree pattern (spirals in shape of waves and ovolos on the edges). According to the excavator, from inside the pendant fell a "stone". On the territory of Crimea, earliest bucket pendants come from 1st century BC graves from within late Scythian cemeteries ${ }^{133}$. Sometime in the 1 st century BC dates grave 2 of type Poienești-Lucășeuca

\footnotetext{
118 Shchukin 2005, 190.

119 Stoyanova 2004, 297; Stoyanova 2016, 131-132; Khrapunov 2011, 39; Khrapunov and Mul'd 2000, 13.

120 Bespalyj 1990, 213, Fig. 1/3, 14.

121 Bubulich and Khakheu 2002, 122, 146, Fig. 6/A3.

122 Khrapunov 2013, 189.

123 With this view also agree E. Istvánovits and V. Kulcsár (Ishtvanovich and Kul'char 2017, 59, note 9).

124 Vaday 1984, 174; Vaday 2016, 767-768; Gulyás 2011, 155; Gulyás 2014, 43.

125 Shchukin 2005, 190.

126 Cf. Ishtvanovich and Kul'char 2017; Bârcă 2018.

127 Shelov 1970, 146; Arsen'eva 1977, 21, Pl. XXIX/2, XXXI/2.

128 Shelov 1970, 146; Arsen'eva 1977, 21, Pl. XXIX/3, XXXI/1.

129 Beilke-Voigt 1998, 55, 68, Fig. 60/I.

130 Cf. Pyatysheva 1956, 18, Pl. VIII/3; Marshall 1969, 184-193, 287, 288, Pl. XXXI/1728-1735, 1772-1782, 1805-1808, LIII/2444-2445; Hoffmann and Davidson 1965, 106, nr. 26, apud Bylkova 1993, 164; Higgins 1980, 159-161, Pl. 47; Korpusova 1983, 56, 57, Fig. 15/1-3, Pl. XIII/3-4, XXIII/6; Symonovich 1983, 92, Pl. XXXI/8, 15; Dashevskaya 1991, 37, Pl. 67/4-6; Bylkova 1993, 164-165, Fig. 1/1; Bârcă 2006a, 71-72, 215, Fig. 34/9, 60/1.

131 Mordvintseva and Trejster 2007, vol. I, 101-103.

132 See for this find and its dating Bylkova 1993, 164-168, Fig. 1-2 (1st century BC); Simonenko 1993, 15-18, 27-29, Fig. 5 (sec.I a. Chr.); Bârcă 2006a, 83, 87, 214-215, Fig. 34 (second half of the 1st century BC); Mordvintseva and Trejster 2007, vol. II, 131-132, cat. no. B40 (2nd - 1st century BC).

133 Bogdanova 1963, Fig. 4/16; Zajtsev 1997, 164, 166, Fig. 3/6, 12; Vysotskaya 1994, 164. According to Yu. P. Zaitsev’s
} 
from Dolineni (Hotin region, Ukraine), whose grave goods contained also two iron bucket pendants, two iron bracelets, a fragmentary bronze bracelet, a bowl, a glass bead and a leaf-shaped brooch of La Tène D1 scheme of type Kostrzewski $\mathrm{H}$ in iron ${ }^{134}$.

Out of the bucket pendants from the Sarmatae graves in the north-west Pontic area, the earliest are in iron from $\mathrm{T}$ 4 at Kholmskoe ${ }^{135}$ (Fig. 2/1-3), dated sometime to the second half/late 1st century BC. Among the grave goods of this richly furnished grave also counts a silver brooch of Middle La Tène scheme (type Kostrzewski B), 30 golden appliques, two bracelets and two silver footrings, 74 beads, an iron knife, a bronze needle and a wheel-thrown $\operatorname{cup}^{136}$.

In the Geto-Dacian space south the Carpathians, earliest known exemplars are those from the cremation barrow graves of Popești (Fig. 6/20-21) and Piscul Crăsani, dated over the course of the 1st century BC or only its second half ${ }^{137}$. In the Dacian environment from the intra-Carpathian area, an iron bucket has been recently discovered in a cremation grave at Piatra Craivii dated to the 1 st century BC, most likely only its second half ${ }^{138}$. An iron exemplar comes also from a Dacian cremation grave (Gr 13) from the Chellenitsya I cemetery ${ }^{139}$ (Fig. 6/17), dated to La Tène D1 ${ }^{140}$, located 150-200 north the Dacian fortification of Mala Kopanya, located in the Upper Tisza area, in Trans-Carpathian Ukraine. Still from Chellenitsya I comes another iron bucket pendant ${ }^{141}$ (Fig. 6/18). It was discovered inside a pyxis discovered outside the graves ${ }^{142}$ together with several beads, a waist belt segment, bronze and iron rings, iron hinges from the waist belt. To these iron pendants also adds a golden specimen (Fig. 6/19, 7/2), of which information specifies only it comes from Chellenitsya $\mathrm{I}^{143}$. Based on the many archaeological materials it was noted that the Chellenitsya I remains date to the chronological span between the late 2nd century BC and early 1 st century $\mathrm{AD}^{144}$.

During the 1 st century $\mathrm{AD}$ - early 2 nd century $\mathrm{AD}$, bucket pendants become increasingly frequent in the late Scythian and Sarmatae environment, being represented by golden, silver, bronze and iron specimens ${ }^{145}$.

It is worth noting that some early exemplars resemble those of the 1st century AD. For instance, the golden bucket pendant from Gr 3 in the Sokolova Mogila barrow (Fig. 3/4, 5), decorated with horizontal ribs in relief (type Beilke-Voigt H, variation I), is similar to that in Gr 180 from the Tanais cemetery, mentioned above. Other three golden bucket pendants from this grave are double and have smooth body surface ${ }^{146}$ (Fig. 3/1), and two are in $\operatorname{iron}^{147}$ (Fig. 3/2-3). The richly furnished grave of Sokolova Mogila barrow dates as already mentioned in the second half of the 1st century AD (possibly the third quarter or even its last third) ${ }^{148}$ and not its first half as dated by G. T. Kovpanenko ${ }^{149}$.

Some of the golden bucket pendants of the 1st century - early 2nd century AD, either common or double, are decorated with filigree patterns, golden granules, incrusted paste or enamel, yet also other decoration elements ${ }^{150}$. For the Sarmatae environment of the north and north-west Pontic area we mention the specimens from T $3 \mathrm{Gr} 3$ at Mikhajlovka $^{151}$ (Fig. 2/19-20), Tsvetna ${ }^{152}$ (Fig. 2/21-22) and T 19 Gr 1 at Karshinskij ${ }^{153}$. The Mikhajlovka grave (T

analysis, tomb 390 in the Ust'-Al'ma cemetery to which belong the common and double bucket pendants dates towards late 2nd century - first half of the 1 st century BC.

134 Smirnova 1981, 195, 204, Fig. 2/3, 3/1-6; Babeş 1993,219, Pl. 47/2a-g.

135 Cf. Gudkova and Fokeev 1984, 10, 23, Fig. 2/16-18; Bârcă 2006, 133-134, 318, Fig. 63/6. Bârcă and Symonenko 2009, 63, Fig. 14/6-8.

136 Cf. Gudkova and Fokeev 1984, 8-10, 21, 23-24, Fig. 2; Bârcă 2006, 317-318, Fig. 63.

137 Vulpe 1976, 198, 208, 214, Fig. 5/10, 6/24; for dating see also Sîrbu et al. 2007, 79.

138 We thank this way our colleague and friend Cristinel Plantos $\mathrm{PhD}$, head of the archaeological excavation site of Piatra Craivii, for reporting this find to us and dating it.

139 Kotigoroshko 2015, 21, 52, 109, 139, 197, 226, Fig. 12/9.

140 Kotigoroshko 2015, 77, 166, 252.

${ }_{141}$ Kotigoroshko 2015, Fig. 69/6.

142 Kotigoroshko 2015, 53, 140, 227, Fig. 69.

143 Kotigoroshko 2015, 51, 139, 226, Fig. 70/4, photo 27/4.

144 Kotigoroshko 2015, 77, 166, 253.

145 See references above.

146 Kovpanenko 1986, 95, 98, Fig. 100/2, 101/3.

147 Kovpanenko 1986, 96, Fig. 100/1. 3, 101/1-2.

148 Bârcă 2011, 10; Bârcă 2015, 41; Simonenko 2011, 43-44.

149 Kovpanenko 1986, 127.

150 Cf. Mordvintseva and Trejster 2007, vol. I, 96-97.

151 Subbotin, Dzigovskij and Ostroverkhov 1998, 21, Fig. 16/5; Dzygovs'kyj 2000, Fig. 43/3; Bârcă 2006,329, Fig. 75/5; Simonenko 2008, 77, cat. no. 107, Pl. 119/5; Bârcă and Symonenko 2009, 163, Fig. 60/3.

152 Simonenko 2008, 69, cat. no. 87, P1. 81/5.

153 Mordvintseva and Trejster 2007, vol. I, 96, vol. II, 38, cat. no. A105.1. 
3 Gr 3) dates based on the richly grave goods sometime to the second half of the 1st century - early 2nd century $\mathrm{AD}^{154}$, the Tsvetna feature to the second half - late of the 1st century $\mathrm{AD}^{155}$, and the Karshinskij grave (T $19 \mathrm{Gr} 1$ ) to the 1 st century $\mathrm{AD}^{156}$. With anthropomorphic figures made by dotting is decorated the bronze bucket pendant from the Lipovets grave ${ }^{157}$ (Fig. 2/18), dated sometime to the second half of the 1st century - first decades of the 2nd century AD.

From Sarmatian graves of the second half of the 1st century - early 2nd century AD come mainly the simple bucket pendants made in gold from the north-east of the Black Sea (the Kuban region). An example to this effect is the Sarmatae grave from T 3 at Kazanskaya, whose grave goods included two golden bucket pendants ${ }^{158}$, yet also the grave in T 42 at Ust'-Labinsk ${ }^{159}$, both from the "Zolotoe kladbishche" cemetery, located on the right bank of the Kuban river. Sometime to the first half of the 2nd century AD also dates the grave in T 38 at Ust'-Labinsk, whose grave goods include a double golden bucket pendant ${ }^{160}$.

In the Sarmatae milieu of the Great Hungarian Plain, a golden pendant decorated on body with granulation comes from the infant grave of Átány ${ }^{161}$ (Fig. 4/6). Beside the pendant were also discovered other golden items ${ }^{162}$, pointing to a dating of the feature sometime in the last quarter/late 1 st century - early 2 nd century AD. The Átány grave, together with other from the same chronologic frame whose grave goods contain bucket pendants, is part of the group of early Sarmatian antiquities from the region. Some graves, including that of Átány, may be ascribed to the so-called "golden horizon"163.

To the second half of the 1st century AD date the bronze bucket pendants from the Geto-Dacian settlement of Ocnița ${ }^{164}$ (Fig. 6/22-23), located south of the Carpathians. Pendants come from a feature (no. 19), with the remains of a jeweller's workshop, dated to the 2 nd century $\mathrm{BC}^{165}$, although its inventory ${ }^{166}$, which also includes a strongly profiled brooch of Eastern type ${ }^{167}$, indicates a dating to the second half of the 1st century AD. One of the pendants of Ocnița seems to belong to type G (Fig. 6/23) in I. Beilke-Voigt's typology ${ }^{168}$. Also, at Ocniţa were found two iron and one bronze bucket pendants ${ }^{169}$ in an infant grave buried with a female ${ }^{170}$. Regarding the bronze specimen, it must be mentioned its body is decorated with two groups of three horizontal ribs in relief each. Based on the dating of feature 19, whose inventory contained two bucket pendants, erroneously dated as shown above, D. Berciu dated this burial to the second half of the 2 nd century BC or no later than its end ${ }^{171}$, although a dating to the 1 st century AD is most plausible. In the summer of 2019, an iron bucket pendant was discovered in a cremation grave of the second half of the 1st century $\mathrm{AD}$ from the Ocnița cemetery ${ }^{172}$. It is in iron and belongs to type $\mathrm{A}$, variation II in I. Beilke-Voigt's typology.

Bucket pendants found associated with artefacts that point to a dating to the 1st century AD are also present in the

\footnotetext{
154 Bârcă 2006,156, 330; Bârcă and Symonenko 2009, 176; Simonenko 2011, 87. A. N. Dzigovskij dates the grave to the 1st century AD (Dzygovs'kyj 1993, 74-75; Dzygovs'kyj 2000, 105), while V. Mordvitseva and M. Trejster to the middle-third quarter of the 1st century AD (Mordvintseva and Trejster 2007, vol. II, 45, cat. no. A129).

155 Simonenko 2008, 15; Simonenko 2011, 40; V. Mordvinceva and M. Trejster date the feature to mid - third quarter of the 1st century AD (Mordvintseva and Trejster 2007, vol. II, 136, cat. no. B46).

156 Mordvintseva and Trejster 2007, vol. II, 38, cat. no. A105.1.

157 Simonenko 2008, 68, cat. no. 82, Pl. 72/2g.

158 Gushchina and Zasetskaya 1994, 42, cat. no. 20, P1. 2/20. Among the grave goods also counts a strongly profiled brooch of Eastern type (cat. no. 22, Pl. 2/22).

159 Gushchina and Zasetskaya 1994, 70, cat. no. 443, 8, P1. 48/443, 8 .

160 Gushchina and Zasetskaya 1994, 68, cat. no. 417, 5, Pl. 45/417, 5.

161 Párducz 1941, 56, P1. XXIX/56

162 Párducz 1941, 56-57, 58, P1. VII/5-7, XXIV/15-22, XXIX/30, 56.

163 For the types of items from finds ascribed to this horizon see Köhegyi 1984; Vaday 1984; Vaday, Istvánovits and Kulcsár 1989, 110-111; Farkas 2000; Ishtvanovich and Kul'char 2005; Istvánovits and Kulcsár 2006; Istvánovits and Kulcsár 2013; Bârcă 2014, 35-69.

164 For the grave goods of this feature which contains a strongly profiled brooch of Eastern type see Berciu 1981, 106, Fig. 91/4-5.

165 Berciu 1981, 106; Berciu 1983, 35. This dating was also adopted by Gh. Bichir (Bichir 1984, 54), I. Beilke-Voigt (BeilkeVoigt 1998, 64), yet also M. B. Shchukin (Shchukin 205, 190).

166 For the grave goods of this feature see Berciu 1981, 105-106, Fig. 91/1-7.

167 For dating these brooches see Rustoiu 1997, 54; Bârcă 2011, 17-18.

168 Cf. Beilke-Voigt 1998, 53, 68, Fig. 58.

169 The pendant's body is decorated with two groups of three horizontal ribs in relief each.

170 Berciu 1983, 34, Fig. 2/1-3.

171 This dating was also adopted by I. A. Bazhan and S. Yu. Kargopol'tsev (Bazhan and Kargopol'tsev 1989, 164).

172 We wish to thank this way our colleague PhD Associate Professor Constantin Bărbulescu, head of the archaeological excavation site of Ocnița, for reporting to us this find and dating it.
} 
Geto-Dacian settlements from the east-Carpathian area, namely Brad (Fig. 6/25-27) ${ }^{173}$, Răcătău ${ }^{174}$ and Poiana ${ }^{175}$. These come from closed features and graves, as well as from the last levels of respective settlements.

In the Dacian environment of the intra-Carpathian area from the period of the 1st century AD such pendants are rare. A bucket pendant, decorated on the external sides with a network of incised lines (Fig. 6/24) was discovered in the settlement of Merești (Harghita county) ${ }^{176}$. Such an iron pendant is supposed to likely come from the Dacian

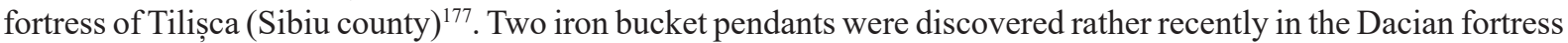
of Ardeu (Hunedoara county) ${ }^{178}$. Eight bucket pendants, in iron (6 pieces) and bronze ( 2 pieces), were discovered in six inhumations (1a, 2a, 8, 16b, 27 (2 pieces), 28a (2 pieces)) in Grădina-Castelului at Hunedoara' ${ }^{179}$ (Fig. 6/3236). In the case of the bronze specimen from burial $16 \mathrm{~b}$, it must be mentioned its body is decorated with zigzag lines forming a row of rhombuses (Fig. 6/32). The eight bucket pendants discovered in various zones of the graves come, with one exception, (the dead in inhumation 27), only from toddler burials ${ }^{180}$. The majority of inhumations with bucket pendants from Hunedoara-Grădina-Castelului were dated to the 1 st century $\mathrm{AD}^{181}$, although a dating to its second half, as mentioned ${ }^{182}$, seems more likely.

In the Przeworsk culture area, earliest bucket pendants come from features and contexts dated to stage B1 in the Central-European chronology, while starting from with stage B2 the number of these artefacts increases significantly in this cultural environment, predominant being those in iron. The massive use of bucket pendants in the Przeworsk culture environment is framed to the chronological interval comprised between the last decades of the 2nd century - early 4th century AD (stages C1-C2), yet they are also found, though rarely, over the 4th century $\mathrm{AD}^{183}$. Although in small numbers, bucket pendants are found during phases $\mathrm{B} 2-\mathrm{C} 1$ also in the Wilbark culture environment. These pendants were massively used in the Sântana de Mureș-Chernyakhov milieu, as confirmed by the many finds from the entire area of this culture ${ }^{184}$, where predominate those in iron, alike the Germanic environment of Central Europe ${ }^{185}$. A ceaseless use of bucket pendants until the 4th century AD is noted for the territory of Crimea, those in bronze being more numerous, while iron specimens date mainly to the late period ${ }^{186}$. Last but not least it must be mentioned that most golden pendants from the late Scythian environment on the territory of Crimea, yet also from the north-Pontic ancient centres are from graves dated to the period comprised between mid 1st century AD and early/first decades of the 2nd century AD. Another note worth mention is related to the double, triple or quadruple bucket pendants coming from the cultural environments of the north-Pontic area only ${ }^{187}$. The latter are made mainly in gold and bronze and originate mainly from graves dated to the chronological interval comprised between mid 1st century $\mathrm{AD}$ and early/first decades of the 2 nd century $\mathrm{AD}^{188}$.

Interestingly to note in the case of double bucket pendants is also the fact that the region where they are found is very close to that where pendants with similar shape yet made of Egyptian faience ${ }^{189}$ were diffused. These Egyptian faience pendants emerge in the north-Pontic area by late 1st century BC, yet are dominant in the 1st - 2nd century graves ${ }^{190}$. On the other hand, it is very likely that double metal bucket pendants had emerged simultaneously or shortly after those simple, in this respect indicative being the association of common bucket pendants and those double from tomb 390 at Ust'-Al'ma, dated by late 2nd century - first half of the 1st century BC ${ }^{191}$.

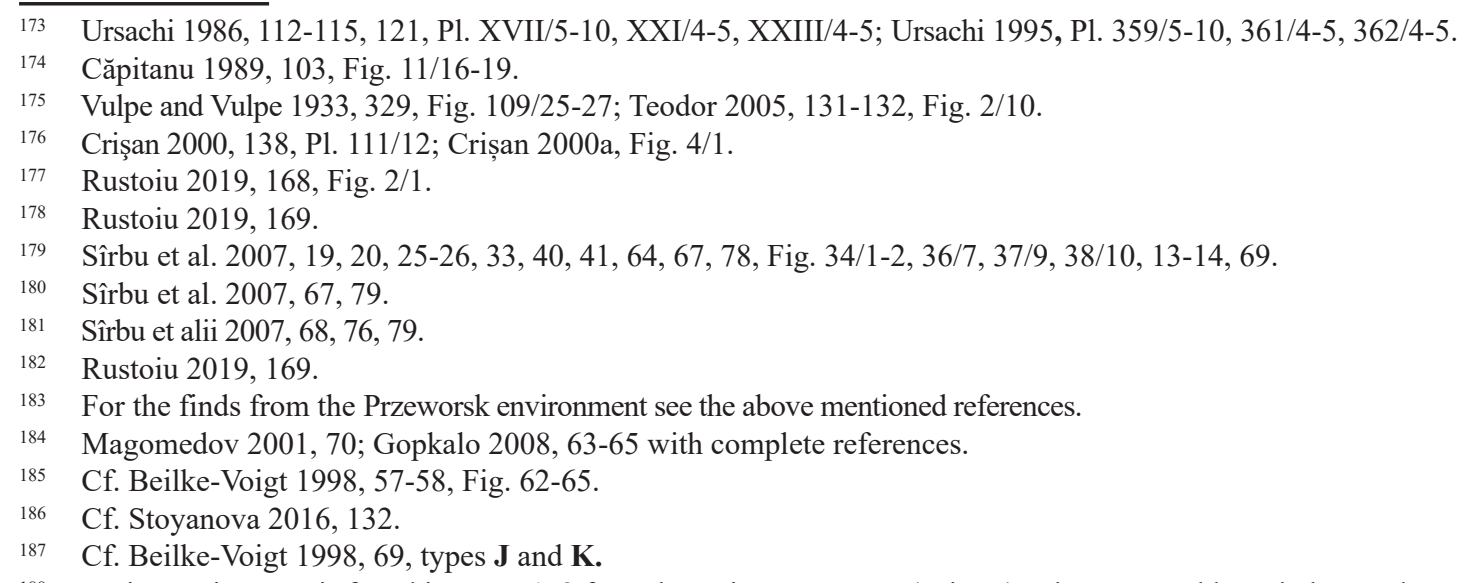

188 An interesting case is found in grave 178 from the Nejzats cemetery (Crimea), where two golden tubular pendants were made of bucket pendants (Khrapunov and Stoyanova 2014, 181, Fig. 4/11; Stoyanova 2016, 130, 131, Fig. 3/15.). The grave is dated based on the grave goods within the limits of the 2nd century AD (Khrapunov and Stoyanova 2014, 183), although the brooch in this grave points to a dating when the Late Sarmatian Period formed, such brooches no longer being found in the late phase of the 2nd century AD (Cf. Kropotov 2010, 213).

189 See for these pendants Alekseeva 1975, 47, types 84-86, Pl. 11/45-46, 13/48; for a series of finds of such pendants see Bârcă 2006, 136 with references.

190 Alekseeva 1975, 47, types 84-86.

191 Cf. Zajtsev 1997, 164, 166, Fig. 3/6, 12. 
Given the above, we wish to emphasize that it is difficult to establish the origin of these artefacts with certainty. Nevertheless, it is increasingly noted that earliest exemplars come from the north-Pontic area and originate in features dated to the 2nd century - 1st century BC, which suggests, at least in the current state of knowledge, that bucket pendants, beside other pendant types, originated in the north-Pontic area ${ }^{192}$. Also, it is hard to say whether bucket pendants derive from the Greek environment of the north of the Black Sea or were produced by artisans in the ancient centres for Barbarian use only. If we keep in mind that the majority of bucket pendants come from the Barbarian environment, we may argue these are their "invention" and specific to their dress. We believe this is supported by both the existence of similar function metal pendants shaped as cauldrons ${ }^{193}$ or miniature "vases"194, as well as the numerous pendant types used by the north-Pontic Barbarian populations.

In the 1st century BC, bucket pendants are present, if we keep in mind the few other finds, with the Late Scythians and Sarmatians from the north and north-western area of the Black Sea. Still in the 1st century BC, concurrently or within a close time span, bucket pendants emerge in the Geto-Dacian (Popești, Crăsani, Piatra Craivii, Chellenitsya I) and Germanic (Dolineni, the Poieneşti-Lucășeuca culture) settings ${ }^{195}$. In these two latter cultural environments, bucket pendants emerged most likely following contacts with the north-Pontic world and by no means via the Sarmatians. Once with the 1st century AD, the number of bucket pendants increases significantly in the late Scythian, Sarmatian and Geto-Dacian environments, yet also in the cemeteries of the towns and settlements from the north-Pontic area. Still in this period they start to be recorded in the Przeworsk culture area, which at the time extended to the current territory of Slovakia.

For the Sarmatian milieu north and north-west Pontic is noted that the great majority of bucket pendants come from graves dated to the chronological interval comprised between mid 1st century D - early/first decades of the 2nd century AD (stages B1b-B2a). Also, such artefacts are rarely found in graves from the second half of the 2nd century AD - first half of the 3rd century AD, yet are also missing in the second stage of the Late Sarmatian Period (the second half of the 3rd century - 4th century AD). Last but not least, it must be mentioned that the golden specimens from the Sarmatae milieu of the north and north-west of the Black Sea are, except for the item in T 17 Gr 1 at Vysochino VII, from graves dated between mid 1st century AD and early/first decades of the 2nd century AD.

The entry and settlement of the Sarmatae in the Great Hungarian Plain led to emergence of these artefacts in this space too, as confirmed by the presence of the golden, bronze and iron bucket pendants in graves from the group of early Sarmatae antiquities in this region. If one keeps in mind these facts, it may be emphasized that the custom of wearing these pendants by women and children was carried to the Great Hungarian Plain in the second half of the 1 st century AD by the first groups of Sarmatae settling this region ${ }^{196}$, which they would in fact inhabit for approximately four centuries.

Today, subsequent to recent bucket pendant finds, yet also the analyses of the Sarmatae funerary features from the Great Hungarian Plain where such artefacts were discovered, it may be argued with certainty that in the Sarmatae milieu of this geographical area, bucket pendants were used to a larger or smaller extent on the entire duration of their inhabitancy there ${ }^{197}$.

Lastly, we wish to mention that the massive use of bucket pendants in the 2 nd -4 th century $\mathrm{AD}^{198}$ in various cultural environments from the area comprised between the north of the Black Sea and Central Europe indicates that during this chronological span they became "supranational" artefacts, being produced and used by various populations from this geographical area, even though in Germanic setting or closely connected to it their use prevails ${ }^{199}$.

\footnotetext{
192 Since earliest bucket pendants are in gold, some decorated in the filigree technique, yet also with other decoration elements, one may assume that these served as prototypes for bronze and iron made pendants.

193 Abramova 1993, 91, Fig. 29/55-58; Gushchina and Zasetskaya 1994, 61, cat. no. 315, Pl. 33/315; Marčenko and Limberis 2008,350 , cat. no. 52, Pl. 80/8.

194 Gushchina and Zasetskaya 1994, 68, cat. no. 417, 2, Pl. 45/417, 2. These are golden made and provided with attachment handle decorated with granules.

195 In the Germanic environment, earliest bucket-shaped pendants, yet which have a much different shape, come from Magdalensberg (Austria) and date to the Late La Tène (Deimel 1987, Pl. 107/12, 15; Beilke-Voigt 1998, 59-60, Fig. 68-69).

196 Cf. Ishtvanovich and Kul'char 2017, 56-57; Bârcă 2018, 44. Once with the 2nd century AD, the silver bucket pendants increase in numbers with the Sarmatae of the Great Hungarian Plain.

197 Cf. Ishtvanovich and Kul'char 2017, 57; Bârcă 2018, 44.

198 For the use of the bucket pendants until early the Migrations period (stage D1) see Harhoiu 1997, 150, 185, cat. no. 68.2

(Pietroasele, M1b (?)), Pl. LXXVII A/15.

199 Cf. Beilke-Voigt 1998, Fig. 76.
} 


\section{REFERENCES}

Abramova, M. P. 1993. Tsentral'noe Predkavkaz'e v sarmatskoe vremya (III v. do n. e. - IV v. n. e.). Moskva: Institut arkheologii Rossijskoj akadmii nauk.

Alekseeva, E. M. 1975. Antichnye busy Severnogo Prichernomor'ya. Arkheologiya SSSR. Svod Arkheologicheskh Istochnikov G 1-12. Moskva: Izdatel'stvo Nauka.

Alekseeva, E. M. 1982. Antichnye busy Severnogo Prichernomor'ya. Arkheologiya SSSR. Svod Arkheologicheskh Istochnikov G 1-12. Moskva: Izdatel'stvo Nauka.

Arkheologiya SSSR. 1989. Stepi evropejskoj chasti SSSR v skifo-sarmatskoe vremya, Izdatel'stvo Nauka, Moskva, 1989.

Arsen'eva, T. M. 1977. Nekropl' Tanaisa. Moskva: Izdatel'stvo Nauka.

Babeş, M. 1993. Die Poieneşti-Lukaşevka Kultur. Ein Beitrag zur Kulturgeschichte im Raum Östlich der Karpaten in den Jahrhunderten vor Christi Geburt. Bonn: Rudolf Habelt Verlag.

Babeş, M. 1999. Ein tamga-zeichen aus der Dakischen siedlung von Ocniţa (Buridava). in: Boroffka and N. Soroceanu, T. (eds.) Transilvanica, Archäologische Untersuchungen zur Ältern Geschichte der südöstlichen Mitteleuropa. Gedenkschrift für Kurt Horedt. Internationale Archäologie. Studia honoraria - Band 7: 223-239. Rahden: Verlag Marie Leidorf.

Babeş, M., Miriţoiu, N., Istrate, M. and Coman, G. 1980. Raport preliminar privind reluarea săpăturilor de la Poieneşti - 1979. Acta Moldaviae Meridionalis 2: 35-44.

Bazhan, I. A. and Kargopol'tsev, S. Yu. 1989. Ob odnoj kategorii ukrashenij-amuletov rimskogo vremeni v Vostochnoj Evrope. Sovetskaya Arkheologiya 3: 163-170.

Bârcă, V. 2006. Istorie şi civilizaţie. Sarmații în spațiul est-carpatic (sec. I a. Chr. - inceputul sec. II p. Chr.). ClujNapoca: Editura Argonaut.

Bârcă, V. 2006a. Nomazi ai stepelor. Sarmaţii timpurii în spaţiul nord-pontic (sec. II-I a. Chr.). Cluj-Napoca: Editura Argonaut.

Bârcă, V. 2011. The fibulae in the North-Pontic Sarmatian Environment (1st C - first half of the 2nd C CE). Ephemeris Napocensis XXI: 7-35.

Bârcă, V. 2013. Nomads of the Steppes by the Danube Frontier of the Roman Empire in the 1st Century CE. Historical sketch and Chronological Remarks. Dacia N. S. LVII: 99-125.

Bârcă, V. 2014. Sarmatian vestiges discovered south of the Lower Mures River. The graves from Hunedoara Timișană and Arad. Cluj-Napoca: Mega Publishing House.

Bârcă, V. 2015. The reinterpretation of the Sarmatian finds from the Romanian Plain (I). Journal of Ancient History and Archaeology 2/1: 35-71. DOI: $10.14795 /$ j.v2i1.105

Bârcă, V. 2015a. A few notes on the emergence and distribution in the Sarmatian environment of variously shaped ditched enclosures, with or without graves inside. in: R. Kogălniceanu, M. Gligor, R.-G. Curcă and S. Stratton (eds.) Homines, Funera, Astra 2. The Archaeology of Death in Ancient Times (Romanian Case Studies). Proceedings of the International Symposium on Funerary Anthropology, 23-26 September 2012, 1 Decembrie 1918 University (Alba Iulia, Romania): 103-118. Oxford: Archaeopress Publishing Ltd.

Bârcă, V. 2018. Notes on the use, dating and origin of the bucket-shaped pendants from the Sarmatian environment of the Great Hungarian Plain. Journal of Ancient History and Archaeology 5/2: 37-63. DOI: 10.14795/j.v5i2.325

Bârcă, V. 2018a. A few notes on the tamgas from the golden plaque in the Sarmatian grave at Dunaharaszti (Hungary). Journal of Ancient History and Archaeology 5/4: 41-65. DOI: 10.14795/j.v5i4.354

Bârcă, V. 2019. Pandantivele-căldărușă din mediul sarmatic. Observații pe marginea originii, datării și utilizării lor. In: C. Croitoru (ed.) Miscellanea Historica et Archaeologica in honorem Professoris Ionel Cândea septuagenarii: 43-75. Editura Academiei Române \& Editura Istros București-Brăila.

Bârcă, V. 2020. The bronze cauldron of Piatra Șoimului (Calu) (Neamț County, Romania). Notes on the distribution, dating and use of such type cauldrons in the Sarmatian environment. Journal of Ancient History and Archaeology 7/1: 79-105. DOI:10.14795/j.v7i1.521

Bârcă, V. 2020a. Funerary Ditched Enclosures in the Sarmatian Funerary Ritual. Observations Regarding Their Introduction, Distribution, Use, and Dating, Ziridava Studia Archaeologica 34: 325-376.

Bârcă, V. and Symonenko, O. 2009. Călăreţii stepelor. Sarmaţii în spaţiul nord-pontic. Cluj-Napoca: Editura Mega.

Bârcă, V., Ursuţiu, A., Cociş, S. I., Stăncescu, R. E., Țuţuianu, C. D., Irimuş, L., Cociş, Al., Sălcudean, C., Bondric, A. and Brehuescu, Al. 2011. Hunedoara Timişană, com. Şagu, jud. Arad, Punct: Autostrada Arad-Timişoara, 
tronson Arad-Seceani, km 23+170 - 23+690 (siturile B0_7-B0_8). Cronica cercetărilor arheologice din România. Campania 2010: 187-192. Sibiu: Muzeul Național Brukenthal.

Beilke-Voigt, I. 1998. Frühgeschichtliche Miniaturobjekte mit Amulettcharakter zwischen Britischen Inseln und Schwarzem Meer. Bonn: Rudolf Habelt Verlag.

Berciu, D. 1981. Buridava dacică. Bucureşti: Editura Academiei Republicii Socialiste România.

Berciu, D. 1983. Morminte de înhumaţie la Ocniţa. Thraco-Dacica IV: 32-38.

Bespalyj, E. I. 1990. Pogrebenie pozdnesarmatskogo vremeni u g. Azova. Sovetskaya Arkheologiya 1: 213-223.

Bichir, Gh. 1973. Cultura carpică. Bucureşti: Editura Academiei Republicii Socialiste România.

Bichir, Gh. 1977. Les Sarmates au Bas-Danube. Dacia N. S. XXI: 167-198.

Bichir, Gh. 1984. Geto-dacii din Muntenia în epoca romană. Bucureşti: Editura Academiei Republicii Socialiste România.

Bierbrauer, V. 1999. Die ethnische Interpretation der Sîntana de Mureş-Černjachov-Kultur. in: G. Fuchs-Gomolka, (ed.) Die Černjachov-Sintana de Mureş-Kultur. Akten des Internationalen Kolloquiums in Caputh vom 20. bis 24. Oktober 1995: 211-238. Bonn: Rudolf Habelt Verlag.

Blume, E. 1912. Die germanischen Stämme und die Kulturen zwischen Oderund Passargezurrömischen Kaiserzeit 1. [Mannus Bibliothek 8]. Würzburg: Kabitzsch Verlag.

Bobrov'ska, O. V. 1997. Do pitannya pro chernyakhivs'ki "vidertsepodibni" prikrasi. in: V. D. Baran (ed.) Problemy pokhozhdennya ta istorichnogo rozvitku slov'yan. Kyiv-L'viv: Izdatel'stvo RAS.

Bogdanova, N. O. 1963. Mogyl'nyk I st. do n. e. - III st. n. e. bilya s. Zavitne Bakhchisarajs'kogo rajonu. Arkheologiya (Kiev) XV: 95-109.

Bubulich, V. G. and Khakheu, V. P. 2002. Issledovanie kurganov v Kamenskom rajone na levoberezh'e Srednego Dnestra. in: Severnoe Prichernomor'e ot eneolita k antichnosti: 112-148. Tiraspol': Editura Tipar.

Budinský-Krička, Lamiová-Schmiedlová 1990

Budinský-Krička, V. and Lamiová-Schmiedlová, M. 1990. A late 1st century BC- 2nd century AD cemetery at Zemplin. Slovenská Archeologia XXXVIII/2: 245-344.

Buyukliev, Hr. 1986. Trakiskiyat mogilen necropol pri Chatalka, Starozagorski okr'g. [Razkopki i proucvanija XVI]. Sofia: Dpzavna Pecatnitsa.

Bylkova, V. P. 1993. Komplex sarmatskogo vremeni iz s. Soloncy Hersonskoj obl., Sovetskaya Arkheologiya 1: 164-168.

Căpitanu, V. 1975. Necropola daco-carpică de incinerație din secolul al III-lea de la Glăvănești-Bărboasa, comuna Oncești, județul Bacău. Carpica VII: 63-116.

Căpitanu, V. 1976. Necropola daco-carpică de la Săuceşti (judeţul Bacău). Carpica VIII: 151-182.

Căpitanu, V. 1989. Obiecte de podoabă şi piese vestimentare descoperite în dava de la Răcătău, jud. Bacău. Carpica XX: 97-124.

Cociş, S. and Bârcă, V. 2014. The "Sarmatian" brooches (headknob and full catchplate variant, Almgren Group VII, Series I) in the Dacia Province and the Barbarian Environment of the Tisza River Basin. Dacia N. S. LVIII: 189-214.

Cociş, S. and Bârcă, V. 2020. Brooches of type Almgren group VII, Series I, variation with headknob and vertical catchplate from the east and south-east of Romania (the Barbarian world). Ephemeris Napocensis XXX: 137-180. Crişan, V. 2000. Dacii din estul Transilvaniei. Sfântu Gheorghe: Carpatii Răsăriteni.

Crişan, V. 2000a. Aspecte privind relaţiile dacilor din estul Transilvaniei cu ţinuturile extracarpatice (sec. II a. Chr. - I p. Chr.). Istros X: 239-249.

Dashevskaya, O. D. 1991. Pozdnie skify v Krymu. Arkheologiya SSSR. Svod Arkheologicheskh Istochnikov D1-7. Moskva: Izdatel'stvo Nauka.

Diaconu, Gh. 1965. Tîrgșor. Necropola din secolele III-IV e. n. București: Editura Academiei Republicii Populare Române.

Diaconu, Gh. 1970. Mogoșani. Necropola din sec. IV e. n., Tîrgoviște: Muzeul Județean Dîmbovița.

Diaconu, Gh. 1986. Gräber des V. Jhs. u. Z. von Pietroasele. Dacia N. S. XXX: 177-180.

Deimel M. 1987. Die Bronzekleinfunde von Magdalensberg. [Archäologische Forschungen zu den Grabungen auf dem Magdalensberg 9], Klagenfurt: Verlag des Landesmuseums für Kärnten.

Droberjar, E. 2002. Encyklopedie ř́mské a germánské archeologie v Čechách a na Moravě. Praha: Libri. 
Dzygovs'kyj, O. M. 1993. Sarmaty na zahodi stepovogo Prychornomor'ya naprykintsi I st. do n. e.- pershij polovyni IV st. n. e. Kyiv: Institut Arkheologii NAN Ukrainy.

Dzygovs'kyj, O. M. 2000. Kul 'tura sarmativ Pivnichno-Zahidnogo Prichornomor'ya. Odesa: Izdatel'stvo Germes.

Farkas, C. 1998. Korai szarmata temetõ aranyleletes sírjai Füzesabony határából (Újabb adatok a szarmata kori viselet problémaköréhez). in: P. Havassy (ed.), Jazigok, roxolánok, alánok. Szarmaták az Alföldön. [Gyulai katalógusok 6]: 67-81. Gyula: Móra Ferenc Múzeum.

Farkas, C. 2000. Kora szarmata sírok Füzesabony határában (Füzesabony-Kastély dülö I). in: T. Petercsák, and A. Váradi (eds.) Heves Megyei Régészeti Közlemények, 2. A népvándorláskor kutatóinak kilencedik konferenciája, Eger, 1998, szeptember 18-20: 15-50. Eger: Heves Megyei Múzeumi Szervezet.

Galanina, L. K. 1973. Vpusknoe pogrebenie I v. n. e. Kurdzhipskogo kurgana. Sovetskaya Arkheologiya 2: 45-59.

Gazdapusztai, G. 1960. Dák-szarmatakori temető és telep Hódmezővásárhely-Kakasszéken. Archaeologiai Értesitö 87/1: 47-50.

Gindele, R. 2015. Roman Period Barbarian Settlements in Partium (Northwestern Romania), Hungarian Archeology, E-Journal, spring 2015, http://files.archaeolingua.hu/2015TA/Gindele_E15TA.pdf

Godłowski, K. 1968. Die Przeworsk-Kultur der mittleren und späten Kaiserzeit. Zeitschrift für Archäologie 2: 256-275.

Godłowski, K. 1970. The chronology of the late Roman and early migration periods in Central Europa. Kraków: Nakładem. Uniwersytetu Jagiellońskiego.

Godłowski, K. 1977. Materiały do poznania kultury Przeworskiej na Górnym Śląsku (Część II). Materiały Starożytne I. Wczesnośredniowieczne IV: 7-237.

Godłowski, K. 1992. Die Przeworsk-Kultur. in: G. Neumann and H. Seemann (eds.) Beiträge zum Verständnis der Germania des Tacitus, Teil II. Bericht über die Kolloquien der Kommission für die Altertumskunde Nord- und Mitteleuropas im Jahre 1986 und 1987: 9-90. Göttingen: Vandenhoeck \& Ruprecht.

Godłowski, K. and Wichman, T. 1998. Chmielów Piaskowy. Ein Gräberfeld der Przeworsk-Kultur im Świętokrzyskie-Gebirge. [Monumenta Archaeologica Barbaria VI]. Kraków: Wydawnictwo i Drukarnia Secesja.

Gopkalo, O. V. 2008. Busy i podveski chernyakhovskoj kul'tury. Kiev: Institut Arkheologii NAN Ukrainy.

Gopkalo, O. V. 2011. Muzhskoj i zhenskij chernyakhovskij kostyum (po dannym pogrebenij s antropologicheskimi opredeleniyami). Stratum plus 4: 179-207.

Gudkova, A. V. and Fokeev, M. M. 1984. Zemledel'tsy i kochevniki v nizov'yah Dunaya I-IV vv. n. e.. Kiev: Izdatel'stvo Naukova dumka.

Gulyás, G. 2011. Szarmata temetkezések Abony és Cegléd környékén. Studia Comitatensia 31: 125-253.

Gulyás, G. 2014. Késö szarmata temetörészletek Óföldeák-Ürmös II. Lelöhelyen (M43-as autópálya 10. lelöhely). A Nyíregyházi Jósa András Múzeum Évkönyve LVI: 15-107.

Gushchina, I. I. and Zasetskaya, I. P. 1994. „Zolotoe kladbishche” Rimskoj epohi v Prikuban'e. Sankt-Peterburg: Izdatel'stvo Farn.

Harhoiu, R. Die frühe Völkerwanderungszeit in Rumänien. Bukarest: Editura Enciclopedică.

Havassy, P. 1998. Katalógus. in: P. Havassy (ed.) Jazigok, roxolánok, alánok. Szarmaták az Alföldön. [Gyulai katalógusok 6]: 145-174. Gyula: Erkel Ferenc Múzeum.

Higgins, R. 1980. Greek and Roman Jewellery, Second Edition. Berkeley-Los Angeles.

Hoffmann, H. and Davidson, P. 1965. Greek Gold. Jewellery from the age of Alexander. Mainz: Philipp von Zabern Verlag.

Ignat, M. 1980. Un cimitir dacic de epocă romană la Podeni-Buneşti (judeţul Suceava). Suceava VI-VII (19791980): 61-75.

Ignat, M. 1999. Dacii liberi din Moldova. Contribuţii arheologice. Necropolele de la Podeni şi Zvorâştea. Iaşi: Editura Helios.

Ioniţă, I. 1977. La nécropole du IV-e siecle de n.e. a Miorcani. Inventaria Archaeologica VIII (R42-R51). Bucarest: Editura Academiei Republicii Socialiste România.

Ioniţă, I. 1982. Din istoria şi civilizaţia dacilor liberi. Dacii din spaţiul est-carpatic in secolele II-IV e. $n$. Iași: Editura Junimea.

Ioniță, I. and Ursachi, V. 1988. Văleni, o mare necropolă a dacilor liberi. Iași: Editura Junimea.

Ishtvanovich, E. and Kul'char, V. 2005. Severoprichernomorskie (?) zolotye yuvelirnye izdeliya v kul'ture 
sarmatov Karpatskogo bassejna. in: V. Yu. Zuev (ed.) Bosporskij fenomen: problemy sootnosheniya pis'menykh $i$ arkeologicheskikh istochnikov: 335-342. Sankt-Peterburg: Izdatel'stvo Gusudarstvennogo Ermitazha.

Ishtvanovich, E. and Kul'char, V. 2017. Vederkovidnye podveski v sarmatskom Barbarikume Karpatskogo bassejna (1-5 vv. n. e). in: A. V. Skyba and S. A. Gorbanenko (eds.) Evropejs'ka arkheologiya I tysyacholittya n. e. Zbirnyk naukovykh ptats' na chest'Liany Vasylivny Vakulenko: 51-61. Kyiv: IA NAN Ukrainy.

Istvánovits, E. 1990. A Felső-Tisza-vidék legkorábbi szarmata leletei, 2-3. századi sírok Tiszavasváriból. A nyíregyházi Jósa András Múzeum Évkönyve XXVII-XXIX, 1984-1986 (1990): 83-133.

Istvánovits, E. 1993. Das Gräberfeld aus dem 4.-5. Jahrhundert von Tiszadob-Sziget, Acta Archaeologica Academiae Scientiarum Hungaricae XLV: 91-146.

Istvánovits, E. and Kulcsár, V. 2006. Az első szarmaták az Alföldön (Gondolatok a Kárpát-medencei jazig foglalásról). A nyíregyházi Jósa András Múzeum Évkönyve XLVIII: 203-237.

Istvánovits, E. and Kulcsár, V. 2013. The „upper class” of Sarmatian society in the Carpathian Basin. in: M. Hardt and O. Heinrich-Tamáska (eds.) Macht des Goldes, Gold der Macht. Herrschafts- und Jenseitsrepräsentation zwischen Antike und Frühmittelalter im mittleren Donauraum. Akten des 23. Internationalen Symposiums der Grundprobleme der Frühgeschichtlichen Entwicklung im Mittleren Donauraum, Tengelic, 16 - 19.11.2011: 195209. Weinstadt: Greiner.

Istvánovits, E. and Kulcsár, V. 2017. Sarmatians - History and Archaeology of the Forgotten People. Mainz: Römisch-Germanischen Zentralmuseums.

Kaczanowski, P. 1980. Wyniki badań na cmentarzysku kultury przeworskiej w Drochlinie, woj. Częstochowa. Sprawozdania Archeologiczne XXXII: 169-190.

Kaczanowski, P. 1987. Drochlin. Ciałopalne cmentarzysko kultury przeworskiej z okresu wptýwów rzymskich. Kraków: Państwowe Wydawnictwo Naukowe.

Kazanskij, M. 2006. Germantsy v yugo-zapodnom Krymu v pozdnerimskoe vremeya i v epokhu Velikogo pereseleniya narodov. in: R. V. Terpilovskij (ed.) Goty i Rim. Kiev: Izdatel'stvo ID Stilos.

Khrapunov, I. N. 2002. Mogil'nik Druzhnoe (III-IV vv. nashej ery) / The cemetery of Droozhnoye. Lublin: Uniwersytetu Marii Curie-Sklodowskiej.

Khrapunov, I. N. 2011. Nekotorye itogi issledovanij mogil'nika Nezajts. in: I. N. Khrapunov (ed.) Issledovaniya mogil'nika Nezajts: 13-114. Simferopol': Izdatel'stvo Dolya.

Khrapunov, I. N. (ed.). 2013. Exploring the Cemetery of Neyzats: collected papers, Simferopol-Kristiansand: Dolya Publishing House.

Khrapunov, I. 2013. Germanic Artefacts in the Cemetery of Neyzats. in: I. Khrapunov and F.-A. Stylegar (eds.) Inter Ambo Maria: Northern Barbarians from Scandinavia toward the Black Sea. [Cultural-historical reports 15]: 177-195. Kristiansand-Simferopol: Dolya Publishing House.

Khrapunov, I. N. and Mul'd, S. A. 2000. Novye issledovaniya mogil'nikov pozdnerimskogo vremeni v Krymu. in: M. Mączyńska and T. Grabarczyk (eds.) Die spätrömische Kaiserzeit und die frühe Völkerwanderungszeit in Mittel-und Osteuropa: 479-521. Łódź: Wydawnictwo Universytetu Lódźkiego.

Khrapunov I. N. and Stoyanova, A. A. 2014. Ob imushchestvennoj i sotsial'noj differentsiatsii naseleniya predgornigo Kryma pozdnerimskogo vremeni, Kratkie soobshcheniya Instituta arkheologii 234: 176-199.

Kobály, J. 1998. A Przeworsk kultúrához tartozó harcossírok és fegyver a Kárpátalján. A nyíregyházi Jósa András Múzeum Évkönyve XXXLX-XL (1997-1998): 113-134.

Korek, J. 1980. Alsónémeti történetének régészeti forrásai a honfoglalás koráig. In: I. Balassa (ed.) Alsónémedi története és néprajza: 9-47. Alsónémedi: Alsónémedi Községi Tanács VB.

Korpusova, V. N. 1983. Nekropol'Zolotoe. Kiev: Izdatel'stvo Naukova dumka.

Kostenko, V. I. 1993. Sarmaty v Nizhnem Podneprov'e (po materialam Uşt'-Kamenskogo mogil'nika). Dnepropetrovsk: Izdatel'stvo DGU.

Kotigoroshko, V. G. 1987. Zhertvennik III-IV vv. u s. Solontsy, Sovetskaya Arkheologiya 2: 176-191.

Kotigoroshko, V. 2015. Sakral'nyj tsentr Verkhn'ogo Potissya Epokhi pizn'ogo Latenu / Centrul sacral al Tisei Superioare în epoca La Tene-ului târziu / The sacred centre of the Upper Tisa region of the Late La Téne period. Satu Mare: Editura Muzeului Sătmărean.

Kovpanenko, G. T. 1986. Sarmatskoe pogrebenie I v. n. e. na Yuzhnom Buge. Kiev: Izdatel'stvo Naukova dumka. Kőhegyi, M. 1984. Kora szarmata aranyleletes női sírok az Alföldön. Debreceni Déei Múzeum Évkönyve 1982 (1984): 267-355. 
Kropotkin, V. V. 1978. Chernyakhovskaya kul'tura i Severnoe Prichernomor'e. in: Kropotkin, V. V., Matiushin, G. N. and Peters, B. G. (eds.) Problemy sovetskoj arkheologii: 147-163. Moskva: Izdatel'stvo Nauka.

Kropotov, V. V. 2010. Fibuly sarmatskoj epokhi. Kiev: Izdatel'stvo ADEF-Ukraina.

Kukharenko, Yu., V. 1958. Ekonomicheskij stroj i byt vostochnykh slavyan v pervoj polovine I tysyacheletiya. in: Ocherki istorii SSSR, vol. II, Krizis rabovlade'cheskoj sistemy i zarozhdenie feodalizma na territorii SSSR III-IX $v v .:$ 52-89. Moskva: Izdatel'stvo Akademii nauk SSSR.

Madyda-Legutko, R., Rodzińska-Nowak, J. and Zagórska-Telega, J. 2011. Opatów, Fpl 1. Ein Gräberfeld der Przeworsk-Kultur im nordwestlichen Kleinpolen. Katalog (1), Tafeln (2). [Fundacja Monumenta Archaeologica Barbarica XV]. Warszava-Kraków: Fundacja Monumenta Archaeologica Barbarica.

Magomedov, B. 2001. Chernyakhovskaya kul'tura. Problema etnosa. Lublin: Uniwersytetu Marii CurieSklodowskiej.

Makhno, E. V. 1961. Razkopki pam'yatok epokhi bronzy ta sarmat'skogo chasu v s. Ust' Kam'yancy. Arheologichni pam'yatki URSR IX: 14-38.

Maksimenko, V. E. 1998. Sarmaty na Donu (arkheologiya i problemy etnicheskoj istorii) (Donskie drevnosti 6), Azov: Azovskij kraevedcheskij muzej.

Marčenko, I. I. and Limberis, N. Ju. 2008. Römische Importe in sarmatischen und maiotischen Denkmälern des Kubangebietes: 265-400, Pl. 1-222. in: A. Simonenko, I. I. Marčenko and Natal'ja Ju. Limberis, Römishe Importe in sarmatischen und maiotischen Gräbern zwischen Unterer Donau und Kuban. [Archäologie in Eurasien 25]. Mainz: Philipp von Zabern.

Marshall, F. H. 1969, Catalogue of the Jewellery, Greek, Etruscan and Roman, in the Departments of Antiquities British Museum. London: British Museum.

Medvedev, A. P. 1990, Sarmaty i lesostep'. Voronezh: Izdatel'stvo Voronezhskogo universiteta.

Mordvintseva, V. and Trejster, M. 2007. Proizvedeniya torevtiki i yuvelirnogo iskusstva v Severnom Prichernomor'e 2 v. do n. e. - 2 v. n. e. vol. I-III. Simferopol'-Bonn: Izdatel'stvo Tarpan.

Nagy, D. S. 2005. Az Orosházi-Tanyák, Máv-homokbánya szarmata temetője. A Szántó Kovács János Múzeum Évkönyve 7: 11-48.

Olędzki, M. 1999. Z problematyki przemian osadniczych i kulturowych na obszarze dorzecza górnej Cisy w wiekach I-IV n. e. in: S. Czopek and A. Kokowski (eds.) Na granicach antycznego świata. Sytuacja kulturowa $w$ poludniowo-wschodniej Polsce i regionach sasiednich $w$ młodszym okresie przedrzymskim i okresie rzymskim: 45-74. Rzeszow: Mitel.

Opreanu, C. H. 1998. Dacia romană şi barbaricum. Timişoara: Editura Mirton.

Palade, V. 1985. Cercetările arheologice din anul 1981 în aşezarea de la Bîrlad - Valea Seacă, Memoria Antiquitatis IX-XI, 1977-1979 (1985): 185-204.

Palade, V. 1986. Nécropole du IV-e et commencement du V-e siecle de n. e. a Bârlad - Valea Seacă. Inventaria Archaeologica. Corpus des ensembles archéologiques (M.-E. Mariën, ed.). Roumanie, Fascicule 12 (R72-R92), Bucarest.

Párducz, M. 1941, A szarmatakor emlékei Magyarországon I / Denkmäler der Sarmatenzeit Ungarns I (Archaeologia Hungarica XXV). Budapest: Akadémiai Kiado.

Párducz, M. 1948. Szarmata temető Hódmezővásárhely-Fehértón. Archaeologiai Értesitő VII-IX (1946-1948): 283-290.

Petrescu, F. 2002. Repertoriul monumentelor archeologice de tip Sântana de Mureş-Cerneahov de pe teritoriul României. Bucureşti: Editura Ars Docendi.

Pop, I. I. 1966. Pandantivele în formă de căldăruşă din sud-estul Transilvaniei. Studii şi Cercetări de Istorie Veche 17, 1: 175-179.

Popilian, Gh. 1980. Necropola daco-romană de la Locusteni. Craiova: Editura Scrisul românesc.

Protase, D. 1976. Un cimitir dacic din epoca romană la Soporu de Cîmpie. Contribuţie la problema continuităţii in Dacia. Bucureşti: Editura Academiei Republicii Socialiste România.

Protase, D. 2002. Obreja. Aşezarea şi cimitirul daco-roman. Secolele II-IV. Dovezi ale continuităţii în Dacia. ClujNapoca: Editura „Neremia Napocae”.

Puzdrovskij, A. E. 2007. Krymskaya Skifiya II v. do n. e. - III v. n. e. Pogrebal'nye pamyatniki. Simferopol': Biznes-Inform.

Puzdrovskij, A. E. and Trufanov, Al. A. 2016. Polevye issledovaniya Ust'-Al'minskogo nekropolya v 2008-2014 gg. Simferopol'-Moskva: IP Brovko A. A. 
Pyatysheva, N. V. 1956. Yuvelirnye izdeliya Khersonesa (Trudy Gosudarstvenogo istoricheskogo muzeya XVIII). Moskva: Gosudarstvennoe Izdate'stvo Kul'turno-prosvetitel'noj literatury.

Radu, C. and Szeredai, N. 2014. Anthropological analysis of a skeletal sample belonging to the Sarmatian population inhabiting the territory at the East of the Pannonian Basin. Journal of Ancient History and Archaeology 1/3: 80-85. DOI: http://dx.doi.org/10.14795/j.v1i3.65

Rafalovich, I. A. 1986. Dancheny. Mogil'nik chernyakhovskoj kul'tury III-IV vv. n. e. Kishinev: Știinţa.

Rikman, E. A. 1975. Pamyatniki sarmatov i plemen chernyakhovskoj kul'tury, [Arkheologicheskaya karta Moldavskoj SSR 5]. Kishinev: Știința.

Romanyuk, L. M. and Symonenko, O. V. 2001. Sarmats'kyj kompleks iz s. Zapruddya na Serednij Naddnipryanshchyni. Arkheologiya (Kyiv) 1: 19-28.

Rustoiu, A. 1996. Metalurgia bronzului la daci (sec. II t.. Chr. - sec. I d. Chr.). Tehnici, ateliere şi produse din bronz. Bucureşti: Institutul Român de Tracologie.

Rustoiu, A. 1997. Fibulele din Dacia preromană (sec. II î. e. n. - I e. n.). Bucureşti: Institutul Român de Tracologie. Rustoiu, A. 2019. Magia ascunsă a unor amulete din Dacia preromană. În legătură cu un pandantiv-căldăruşă din sudul Transilvaniei. Analele Banatului S.N. XXVII: 167-176.

Ruxer, M. S. and Kubszak, J. 1972. Naszyjnik grecki w okresach hellenistycznym i zymskim. Warszawa-Poznań: Państwowe Wydawnictwo Naukowe Oddział w Poznaniu.

Shchukin, M. B. 2005. Gotskijput'. Goty, Rimi Chernyakhovskaya kul 'tura. Sankt-Peterrburg: Filologicheskijakul'tet SpbGU.

Shelov, D. B. 1961. Nekropol' Tanaisa (Materialy i issledovanya po arkheologii 98). Moskva: Izdatel'stvo Akademii Nauk SSSR.

Shelov, D. B. 1970. Tanais i Nizhnij Don v ervye veka nashej ery. Moskva: Izdate'stvo Nauka.

Simonenko, A. V. 1993. Sarmaty Tavrii. Kiev: Izdatel'stvo Naukova dumka.

Simonenko, A. V. 2004. Khronologiya i periodizatsiya sarmatskh pamyatnikov Severnogo Prichernomor'ya. in: B. A. Raev (ed.) Sarmatskie kul'tury Evrazii: problemy regional'noj khronologii. Doklady k 5-j mezhdunarodnoj konferentsii "Problemy sarmatskoj arkheologii i istorii": 134-173. Krasnodar.

Simonenko, A. V. 2008. Römische Importe in sarmatischen Denkmälern des nördlichen Schwarzmeergebietes: 1-94, Pl. 1-168. in: A. Simonenko, I. I. Marčenko and Natal'ja Ju. Limberis, Römishe Importe in sarmatischen und maiotischen Gräbern zwischen Unterer Donau und Kuban. [Archäologie in Eurasien 25]. Mainz: Philipp von Zabern.

Simonenko, A. V. 2011. Rimskij import u sarmatov Severnogo Prichernomor'ya. Sankt-Peterburg: Nestor-Istoriya. Sirbu, V., Luca, S. A., Roman, C., Purece, S., Diaconescu, D. and Cerişer, N., Vestigiile dacice de la Hunedoara / Dacian vestiges in Hunedoara. Alba-Iulia: Altip.

Smirnov, K. F. 1964. Savromaty. Rannyaya istoriya i kul'tura sarmatov. Moskva Izdate'stvo Nauka.

Smirnova, G. I. 1981. Mogil'nik tipa Poyaneshty-Lukashevka u s. Dolinyany na Bukovine (raskopki 1977-1978 gg.). Sovetskaya Arkheologiya 3: 193-207.

Spânu, D. 2014-2015. Mica necropolă din secolele II-III p. Chr. de la Sighişoara-Dealul Viilor. Marisia XXXIVXXXV: 39-56.

Stoyanova, A. A. 2004. Busy i podveski iz mogil'nika Nezajts (po materialam raskopok 1996-2001 gg.). in: A. I. Ajbabin (ed.) Bosporskie issledovaniya V: 263-319. Simferopol'-Kerch': Izdatel'stvo Demetra.

Stoyanova, A. A. 2016. Podveski iz mogil'nika Nezajts. in: I. Khrapunov (ed.) Krym v sarmatskuyu epokhu (II v. do n. e. $-I V$ v. n. e.), II. 20 let issledovanij mogil'nika Nejzats: 122-165. Simferopol': Izdatel'stvo Nasledie tysyachiletii.

Subbotin, L. V., Dzigovskij, A. N. and Ostroverkhov, A. S. 1998. Arkheologicheskie drevnosti Budzhaka. Kurgany u sel Vishnevoe i Beloles'e, II. Odessa-Kyiv: Institut Arkheologii NAN Ukrainy.

Symonenko, O. V. 1999. Sarmaty Pivnichnogo Prychornomor'ya. Khronologiya, periodyzatsiya ta etno-politychna istoriya. Avtoreferat dysertatsii na zdobuttya stupenya doktora istorychnyh nauk. Kyiv.

Symonovich, E. A. 1983. Naselenie stolitsy pozdneskifskogo tsarstva (po materialam Vostochnogo mogil'nika Neapolya skifskogo. Kiev: Izdatel'stvo Naukova dumka.

Szela, A. 2007. Nietypowy zespót grobowy z cmentarzyska kultury przeworskiej w Biejkowie, stan. 9, pow. Białobrzegi. Folia Archaeologica 25: 285-293.

Szydłowski, J. 1964. Cmentarzysko z okresu wpływów rzymskich w Choruli, pow. Krapkowice. Wrocław: Zakład narodowy imienia Ossolińskich. 
Szydłowski, J. 1974, Trzy cmentarzyska typu dobrodzieńskiego. Bytom: Muzeum Górnośląskie w Bytomiu. Şovan, O. L. 2009. Necropola de tip Sântana de Mureş - Černjachov de la Mihălăşeni (jud. Botoşani). Târgoviște: Editura Cetatea de Scaun.

Tejral, J. 1999. Die Völkerwanderungen des 2. und 3.Jhs und ihr Niederschlag im archäologischen Befund des Mitteldonauraumes. In J. Tejral (ed.) Das mitteleuropäische Barbaricum und die Krise des römischen Weltreiches im 3. Jahrhundert. [Spisy Archeologického Ústavu AVČR Brno 12]: 137-213. Brno: Archeologický ústav AVČR.

Tejral, J. 2011. Die nachträglichen germanischen Siedlungsaktivitäten am Burgstall bei Mušov. Versuch einer Interpretation. Přehled výzkumů 52/2: 39-73.

Tempelmann-Mączyńska, M. 1989. Das Frauentrachtzubehör des mittel- und osteuropäischen Barbaricums in der römischen Kaiserzeit. Kraków: Jagiellonen-Universität.

Teodor, S. 2005. Necropola tumulară de la Poiana, județuil Galați, in: P. Roman and D. Ciobanu (eds.) In memoriam Ion Nestor: 129-136.Buzău: Alpha MDN.

Trufanov, Al. A. 2009. Khronologiya mogil'nikov Predgornogo Kryma I v. do n. e. - III v. n. e. Stratum plus 4 (2005-2009): 117-328.

Ursachi, V. 1986. Rituri şi ritualuri de înmormântare la populaţia dacică din cetatea de la Brad, comuna Negri, județul Bacău. Memoria Antiquitatis XII-XIV, 1980-1982 (1986): 105-151.

Ursachi, V. 1995, Zargidava. Cetatea dacică de la Brad. Bucureşti: Institutul Român de Tracologie.

Ursulescu, N, Sîrbu, V., Oţa, L., Şadurschi, P. and Diaconescu, M. 2019. Mormintele sarmatice de la Prăjeni (judeţul Botoşani). Materiale şi Cercetări Arheologice XVII, 165-199.

Vaday, A. 1984. Das Graberfeld der Jazyges Metanastae in Mezöcsát-Hörcsögös. Mitteilungen des Archäologischen Instituts der Ungarischen Akademie der Wissenscheften 12-13, 1982-1983 (1984): 167-188, 383-392.

Vaday, A. H. 1989. Die sarmatischen Denkmäler des Komitats Szolnok (Antaeus 17-18, 1988-1989). Budapest: Archäologisches Inst. der UAW.

Vaday, A. 2016. A szarmata barbaricum határvidékén. in: T. Csécs and M. Takács (eds.) Beatus homo qui invenit sapientiam. Ünnepi kötet Tomka Péter 75. Születésnapjára: 757-788. Győr: Lekri Group.

Vaday, A. and Szőke, B. M. 1983. Szarmata temetö és gepida sír Endrőd-Szujókereszten. Communicationes Archaeologicae Hungaricae 1983: 79-132.

Vaday, A., Istvánovits, E. and Kulcsár, V. 1989. Sarmatian costume in the Carpathian Basin. Klio 71/1: 107-114.

Vakulenko, L. V. 1999. Beiträge zur ethnischen Bestimmung des Gräberfeldes von Solonzi / Kisszelmenc (Karpatoukraine). A Nyíregyházi Jósa András Múzeum Évkönyve XLI: 161-172.

Vornic, V. 2006. Așezarea și necropola de tip Sântana de Mureș-Černjahov de la Budești. Chişinău: Editura Pontos. Vornic, V., Bubulici, V. and Popovici, S. 2015. Date preliminare privind necropola sarmatică de la Medeleni (com. Petrești, r-nul Ungheni). Arheologia Preventiva în Republica Moldova II: 59-72.

Vornic, V., Bubulici, V. and Popovici, S. 2016. Sarmatian necropolis from Medeleni (com. Petreşti, Ungheni District, Republic of Moldova), Journal of Ancient History and Archaeology 3/3: 20-48. DOI: 10.14795/j.v3i3

Vörös, G. 1981. Adatok a szarmatakori női viselethez. Communicationes Archaeologicae Hungaricae 1981: 121135.

Vulpe, Al. 1976. La nécropole tumulaire gète de Popeşti. Thraco-Dacica I: 193-215.

Vulpe, R. and Vulpe, Ec. 1933. Fouilles de Poiana. Dacia III-IV, 1927-1932 (1933): 253-351.

Vyaz'mitina, M. I. 1972. Zolotobalkovskij mogil'nik. Kiev: Izdatel'stvo Naukova Dumka.

Vysotskaya, T. N. 1994. Ust'-Al'minskoe gorodishche i nekropol'. Kiev: Kievskaya Akademiya Evrobiznesa.

Zajtsev, Yu. P. 1997. Sklep nr. 390 Ust'-Al'minskogo pozdneskifskogo nekropolya. in: I. N. Khrapunov (ed.)

Bakhchisarajskij istoriko-arkheologicheskij sbornik I: 156-166. Simferopol': Izdatel'stvo Tavriya.

\section{LISTA ILUSTRAȚIILOR}

Fig. 1. Pandantive-căldărușă. 1. Hunedoara Timișană, mormântul 9; 2. Hunedoara Timișană, mormântul 13 (după Bârcă 2014); 3. Zîrneşti, T 1 M 5 (după Rikman 1975); 4-5. Bădragii Vechi, T 7 M 4 (după Bârcă 2006); 6. Kazanskaya, T 3 (după Gushchina și Zasetskaya 1994); 7. Zaprud'e (după Simonenko 2008); 8-10. Chertovitsk 
I, T 2/41 M 1 (după Medvedev 1990); 11-13. Vysochino VII, T 17 M 1 (după Bespalyj 1990); 14. Chertovitsk, II T 11 M 1 (după Medvedev 1990); 15. Ust'-Kamenka, T 5 M 1 (după Simonenko 2008); 16. Semnul tamga de pe pandantivul din T 19 M 1 de la Karshinskij (după Mordvintseva și Trejster 2007). 1-5. Fier; 7-10, 14-15. Bronz; 12-13. Argint; 6, 11. Aur.

Fig. 2. Pandantive-căldărușă din morminte sarmatice din spațiul nord și nord-vest pontic. 1-3. Kholmskoe, T 4 (după Gudkova și Fokeev 1984); 4. Podojma, T 3 M 3 (după Bubulich și Khakheu 2002); 5. Lencovtsy, T 1 M 2 (după Bârcă 2006); 6. Medeleni, mormântul 3 (după Vornic, Bubulici şi Popovici 2016); 7-16. Pisarevka, T 1 M 8; 17. Chuguno-Krepinka, T 2 M 1; 18. Lipovets (după Simonenko 2008); 19-20. Mikhajlovka, T 3 M 3 (după Simonenko 2008 (19), Istvánovits și Kulcsár 2017 (20); 21-22. Tsvetna (după Simonenko 2008 (21), Mordvintseva și Trejster 2007 (22). 19-22. Aur; 4, 6, 18. Bronz; 1-3, 5, 17. Fier.

Fig. 3. Pandantive-căldăruşă din mormântul sarmatic din tumulul Sokolova Mogila (1-5) și T 2 M 9 de la PrăjeniȚarnă (6-8) (1-5 - după Kovpanenko 1986; 6-8 - după Ursulescu et al. 2021). 1, 4. Aur; 6-8. Bronz; 2-3. Fier.

Fig. 4. Pandantive-căldărușă din morminte sarmatice din Câmpia Panonică. 1. Kiskőrös-Csukás tó-Rácz kút, mormântul 6 (după Párducz 1941); 2. Orosházi-tanyák, mormântul 11 (după Nagy 2005); 3. EndrődSzujókereszt, mormântul 45 (după Vaday și Szőke 1983); 4. Abony-Kisbalaton-dülö, mormântul 36 (după Gulyás 2011); 5. Füzesabony-Kastély dülő I, mormântul 150 (după Farkas 2000); 6. Átány (după Párducz 1941 ); 7. Mezöcsát-Hörcsögös, mormântul 63; 8. Mezöcsát-Hörcsögös, mormântul 1 din aşezare (după Vaday 1984); 9. Hódmezővásárhely-Fehértó, mormântul 6 (după Ishtvanovich și Kul'char 2017); 10. Tiszadob-Sziget, mormântul 11; 11. Tiszadob-Sziget, mormântul 28 (după Istvánovits 1993); 12. Tiszavasvári,Vároföldje-Jegyzö-tag, mormântul 7 (după Istvánovits 1990); 13. Nyíregyháza-Felsősima, mormântul 39 (după Istvánovits și Kulcsár 2017). 6, 13. Aur; 2, 12. Argint; 1, 3, 7-9. Bronz; 4-5, 10-11, Fier. Fără scară.

Fig. 5. Pandantive-căldărușă din mormântul sarmatic de la Kálló. 1-4. Argint; 5. Reconstituire pandantiv-căldăruşă din argint; 6-15. Fier (după Vaday 2016).

Fig. 6. Pandantive-căldărușă. 1-12. Zemplin, mormântul 22; 13-16. Zemplin, mormâmtul 48 (după BudinskýKrička şi Lamiová-Schmiedlová 1990); 17. Chellenitsya I, mormântul 13; 18-19. Chellenitsya I (după Kotigoroshko 2015); 20-21. Popești (după Vulpe 1976); 22-23, 28-30. Ocnița (după Berciu 1981; 1983); 24. Merești (după Crișan 2000); 25-27. Brad (după Ursachi 1995); 31. Poiana, tumulul 4 (după Teodor 2005); 32-36. HunedoaraGrădina Castelului (după Sîrbu et al. 2007). 19. Aur; 30, 32. Bronz; 1-18, 20-29, 31, 33-36. Fier. Fără scară.

Fig. 7. Pandantive-căldăruşă. 1, 7-13. Nejzats (după Stoyanova 2016); 2. Chellenitsya I (după Kotigoroshko 2015); 3. Suplacu de Barcău (după Gindele 2015); 4-5. Olbia (după Mordvintseva şi Trejster 2007); 6. Ust'-Al'ma (după Puzdrovskij 2007); 14-16. București-Militari (după Bichir 1984); 17-18. Poienești; 19-20. Pădureni (după Bichir 1973); 21-28. Solontsy (după Kotogoroshko 1987). 1-5. Aur; 7. Argint; 6. Bronz; 8-28. Fier. 1-5. Fără scară.

VITALIE BÂRCĂ Institute of Archaeology and History of Art Cluj-Napoca vitalie_barca@yahoo.com 


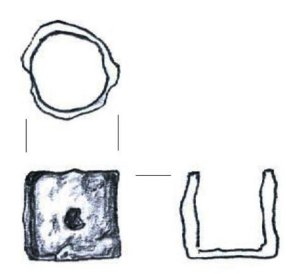

1

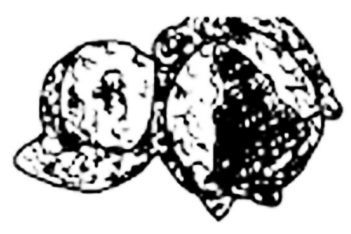

4<smiles>C1=CCCCCCCCCCC1</smiles>

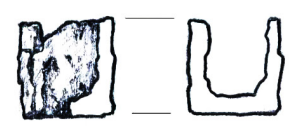

2

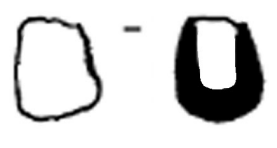

3
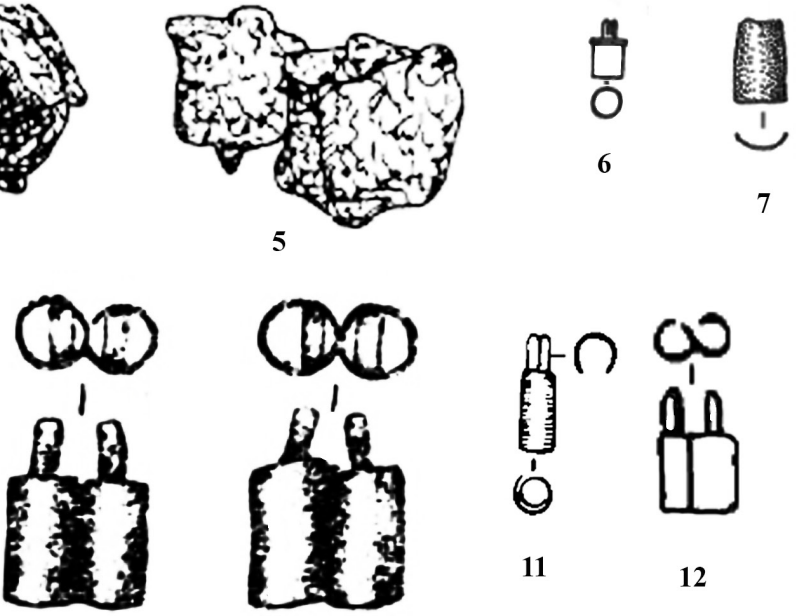

9
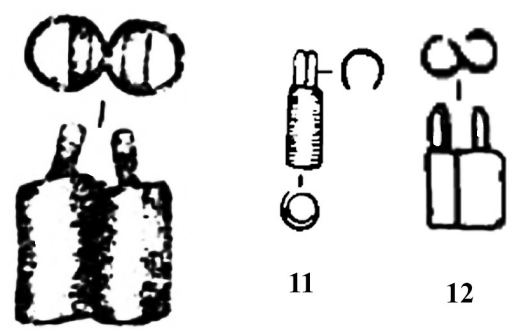

12

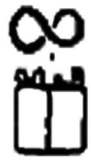

11

13

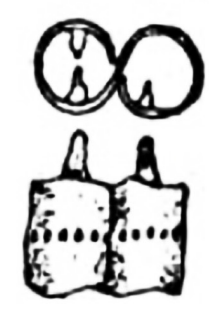

14
10
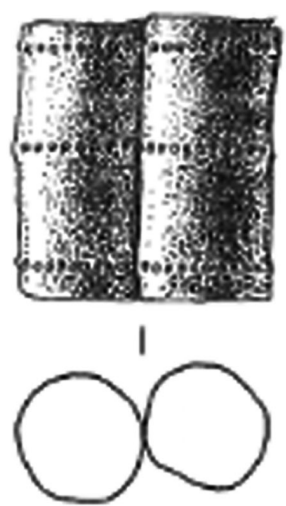

15

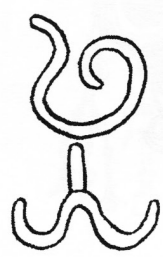

16

$\mathbf{0}$

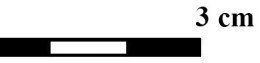

Fig. 1. Bucket-shaped pendants. 1. Hunedoara Timișană, grave 9;

2. Hunedoara Timișană, grave 13 (after Bârcă 2014);

3. Zîrneşti, T 1 G 5 (after Rikman 1975);

4-5. Bădragii Vechi, $T 7$ G 4 (after Bârcă 2006);

6. Kazanskaya, T 3 (after Gushchina and Zasetskaya 1994);

7. Zaprud'e (after Simonenko 2008);

8-10. Chertovitsk I, T 2/41 G 1 (after Medvedev 1990);

11-13. Vysochino VII, T 17 G 1 (after Bespalyj 1990);

14. Chertovitsk, II T 11 G 1 (after Medvedev 1990);

15. Ust'-Kamenka, T 5 G 1 (after Simonenko 2008);

16. The tamga on the pendant of $T 19 \mathrm{G} 1$ at Karshinskij (after Mordvintseva and Trejster 2007).

1-5. Iron; 7-10, 14-15. Bronze; 12-13. Silver; 6, 11. Gold. 


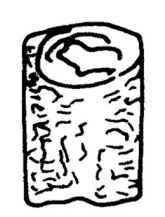

1

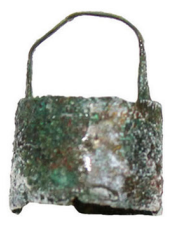

6

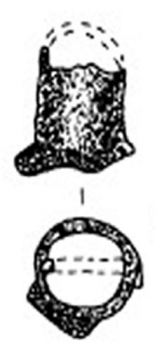

14

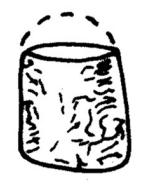

2

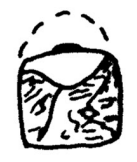

3

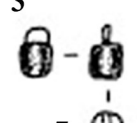

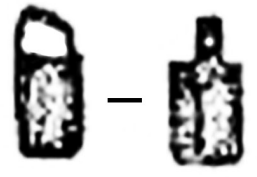<smiles>c1ccccc1</smiles>

4

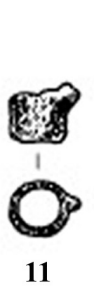

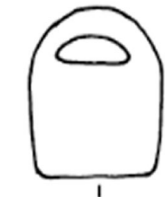

5

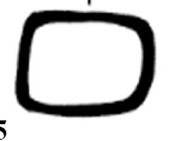

스

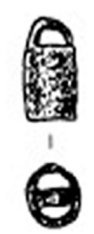

8
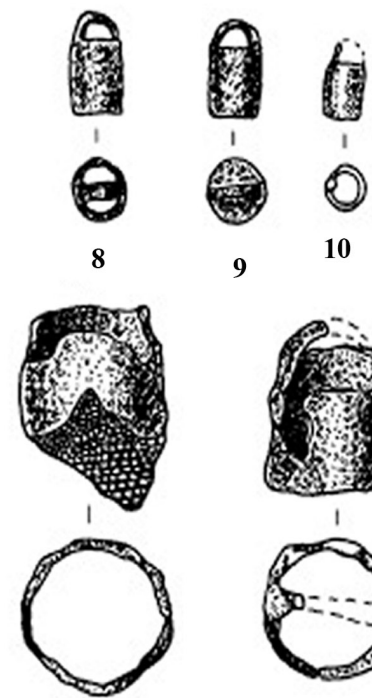

15

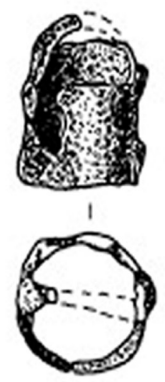

16

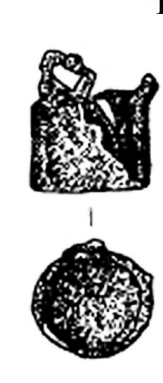

17

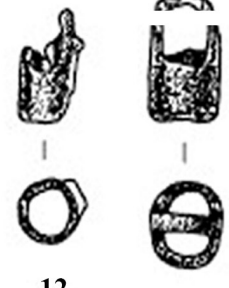

13

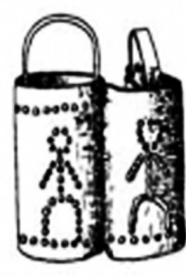

18

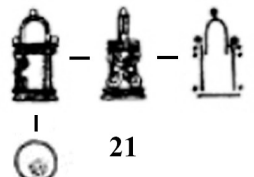

20

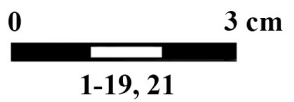

Fig. 2. Bucket-shaped pendants from Sarmatian graves in the north and north-west Pontic area.

1-3. Kholmskoe, $T 4$ (after Gudkova and Fokeev 1984);

4. Podojma, T 3 G 3 (after Bubulich and Khakheu 2002); 5. Lencovtsy T 1 G 2 (after Bârcă 2006);

6. Medeleni, grave 3 (after Vornic, Bubulici and Popovici 2016);

7-16. Pisarevka, $T 1 G 8$;

17. Chuguno-Krepinka, $T 2$ G 1 ;

18. Lipovets (after Simonenko 2008);

19-20. Mikhajlovka, T 3 G 3 (after Simonenko 2008 (19), Istvánovits and Kulcsár 2017 (20);

21-22. Tsvetna (after Simonenko 2008 (21), Mordvintseva and Trejster 2007 (22).

19-22. Gold; 4, 6, 18. Bronze; 1-3, 5, 17. Iron. 


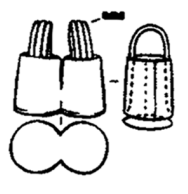

1

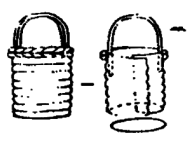

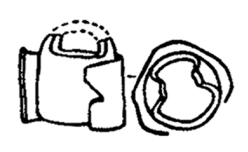

2

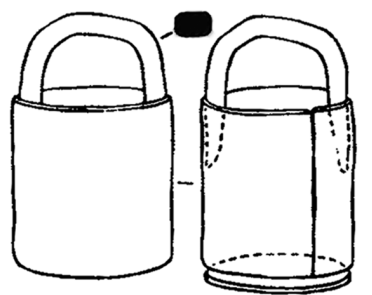

3

4

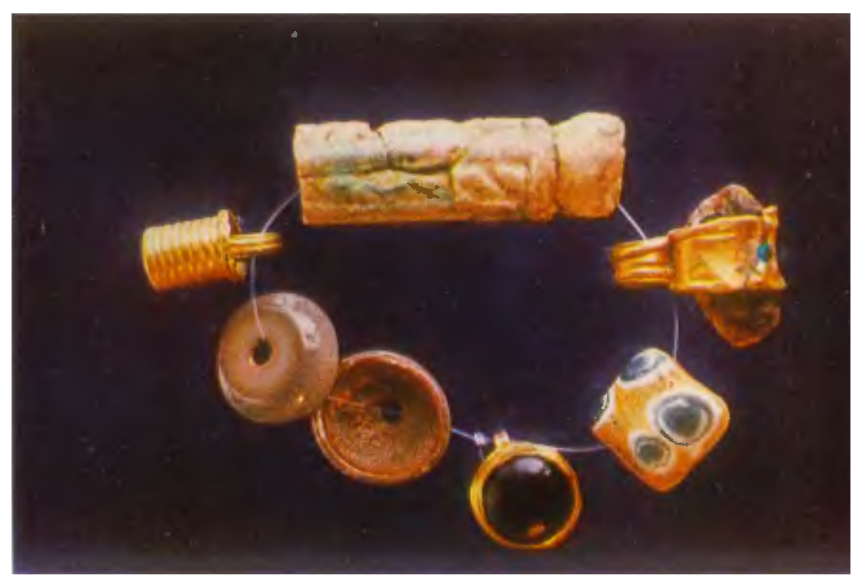

5

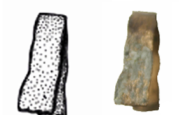

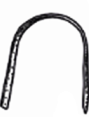
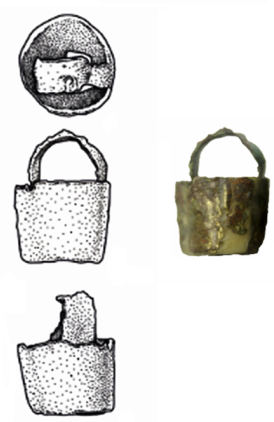

0
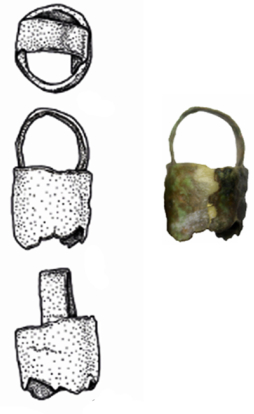

8

Fig. 3. Bucket-shaped pendants from the Sarmatian grave in the barrow at Sokolova Mogila (1-5) and T 2 M 9 from Prăjeni-Tarnă (6-8)

(1-5 - after Kovpanenko 1986;

6-8 - after Ursulescu et al. 2021)

1, 4. Gold; 6-8. Bronze; 2-3. Iron. 

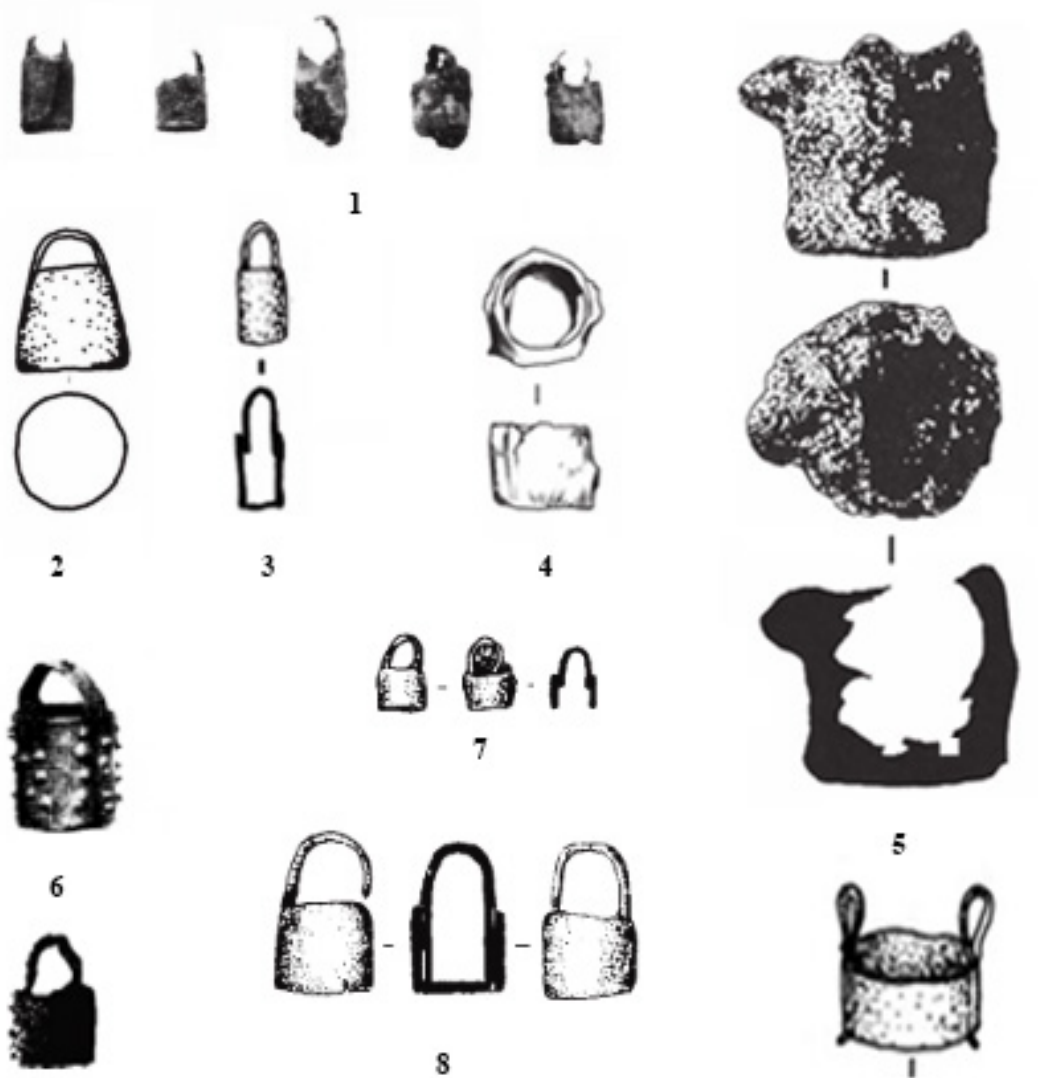

8

9
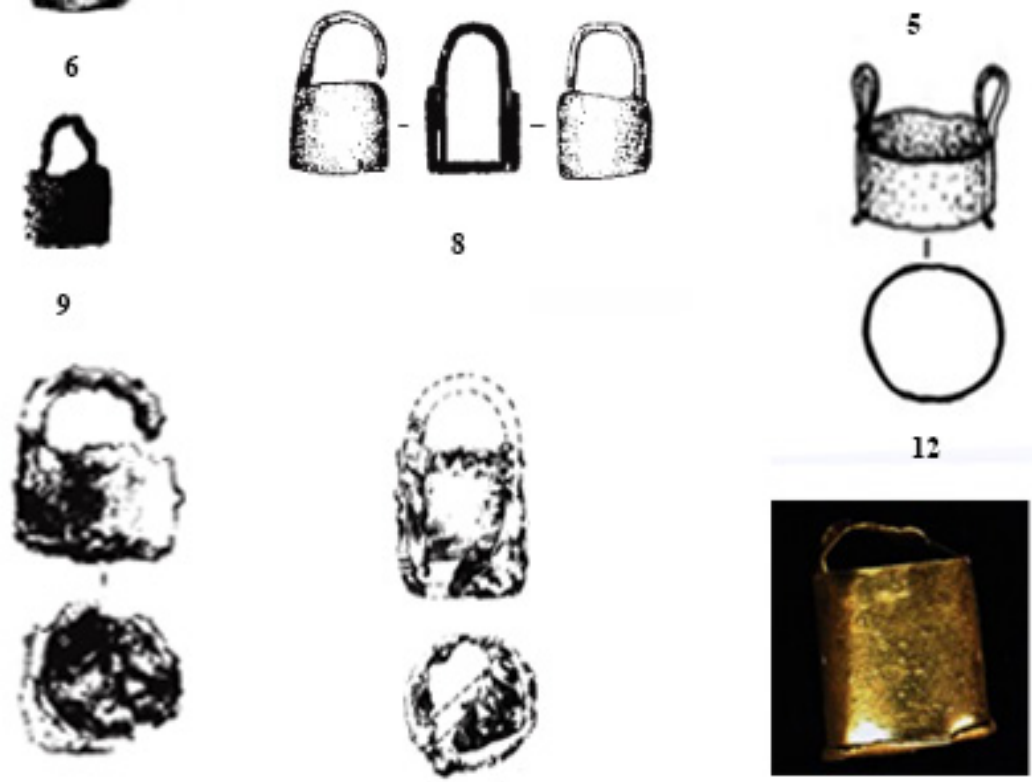

10

11

13

Fig. 4. Bucket-shaped pendants from Sarmatian graves of the Great Hungarian Plain.

1. Kiskörös-Csukás tó-Ráczkút, grave 6 (after Párducz 1941);

2. Orosházi-tanyák, grave 11 (after Nagy 2005);

3. Endröd-Szujókereszt, grave 45 (after Vaday, Szöke 1983);

4. Abony-Kisbalaton-dülö, grave 36 (after Gulyás 2011);

5. Füzesabony-Kastély dülö I, grave 150 (after Farkas 2000); 6. Átány (after Párducz 1941);

7. Mezöcsát-Hörcsögös, grave 63;

8. Mezöcsát-Hörcsögös, grave 1 from the settlement (after Vaday 1984);

9. Hódmezövásárhely-Fehértó, grave 6 (after Ishtvanovich and Kul'char 2017); 10. Tiszadob-Sziget, grave 11;

11. Tiszadob-Sziget, grave 28 (after Istvánovits 1993);

12. Tiszavasvári, Vároföldje-Jegyzö-tag, grave 7 (after Istvánovits 1990);

13. Nyíregyháza-Felsösima, grave 39 (after Istvánovits and Kulcsár 2017).

6, 13. Gold; 2, 12. Silver; 1, 3,7-9. Bronze; 4-5, 10-11, Iron. Without scale. 


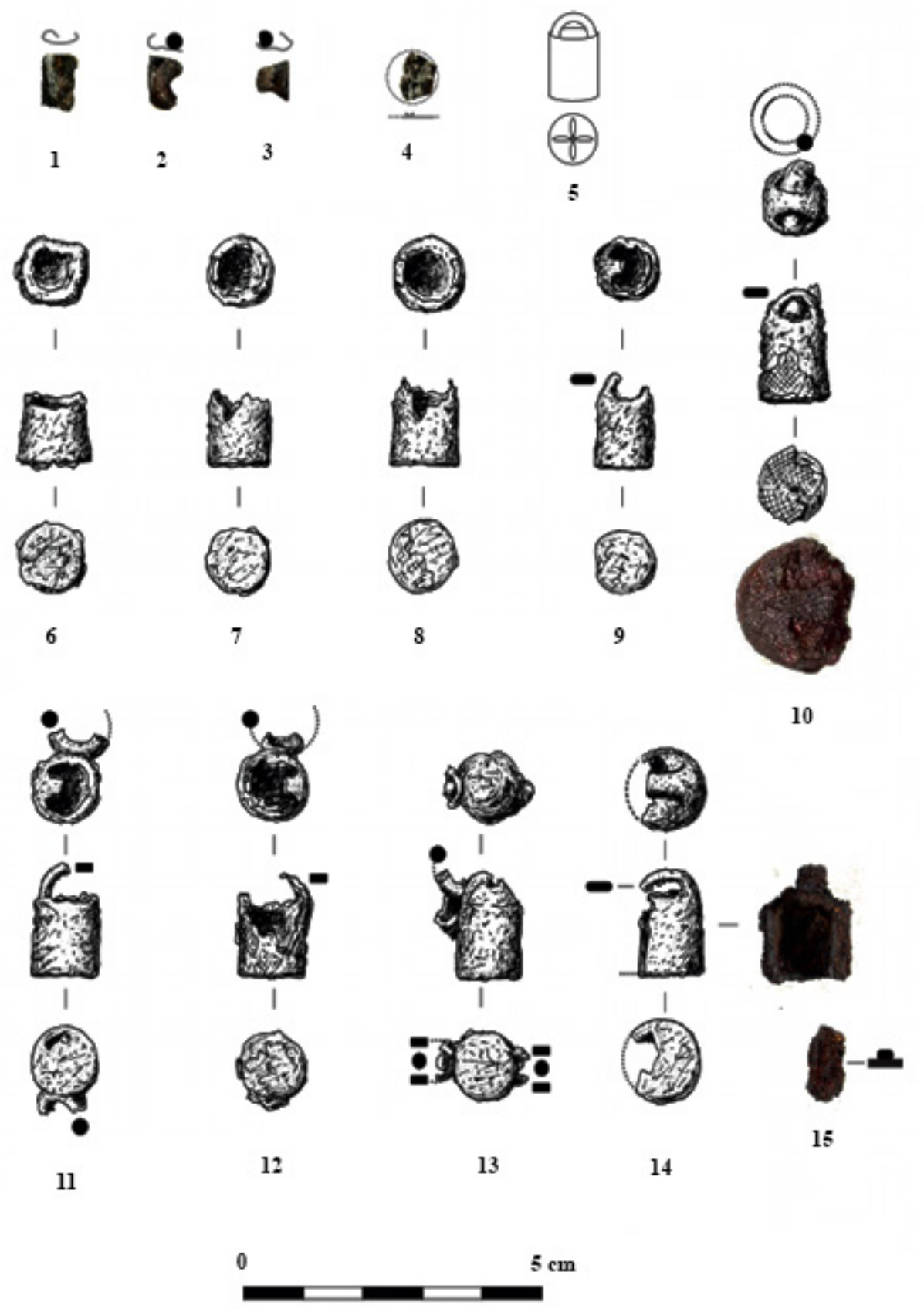

Fig. 5. Bucket-shaped pendants from the Sarmatian grave at Kálló. 1-4. Silver;

5. Reconstruction of the silver bucket-shaped pendant; 6-15. Iron (after Vaday 2016). 


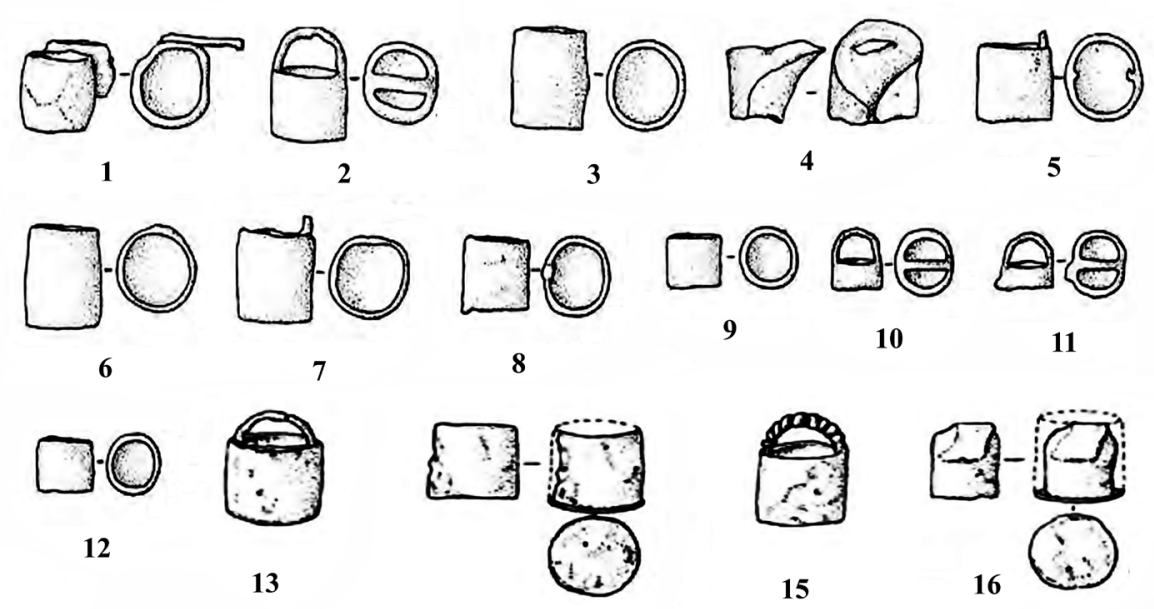

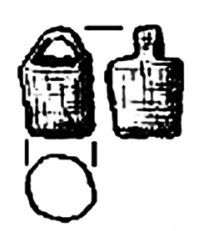

17

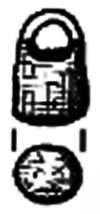

18

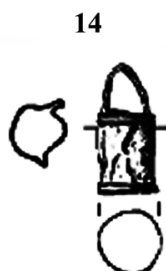

19

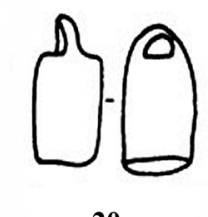

20

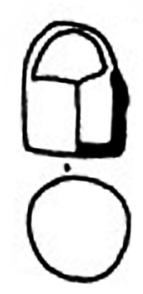

25

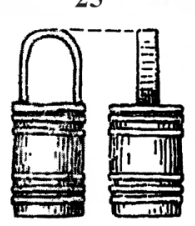

30

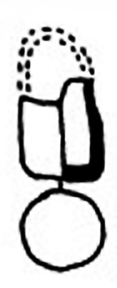

26

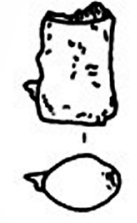

21

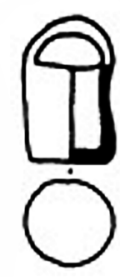

27

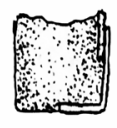

31
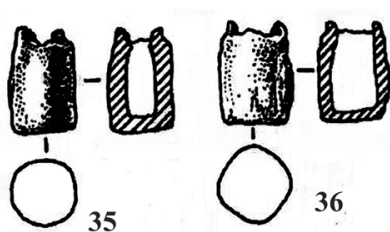

35

32

33
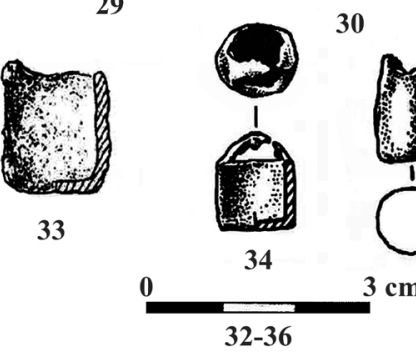

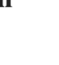

Fig. 6. Bucket-shaped pendants.

1-12. Zemplin, grave 22;

13-16. Zemplin, grave 48 (after Budinský-Krička and Lamiová-Schmiedlová 1990);

17. Chellenitsya I, grave 13;

18-19. Chellenitsya I (after Kotigoroshko 2015);

20-21. Popești (after Vulpe 1976); 2

2-23, 28-30. Ocnița (after Berciu 1981),

24. Merești (after Crișan 2000);

25-27. Brad (after Ursachi 1995);

31. Poiana, tumulus 4 (after Teodor 2005);

32-36. Hunedoara-Grădina Castelului (after Sirbu et al. 2007).

19. Gold; 30, 32. Bronze; 1-18, 20-29, 31, 33-36. Iron. Without scale. 


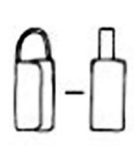

1

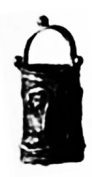

4

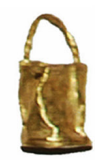

2
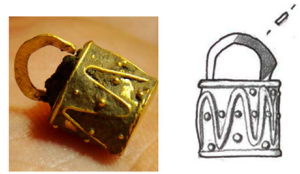

3

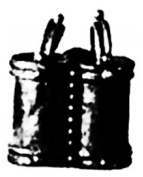

5
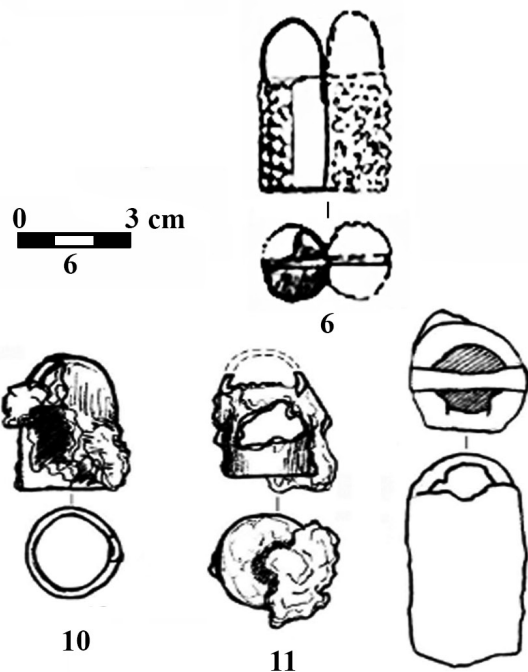

12

13

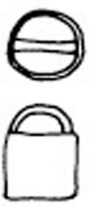

14

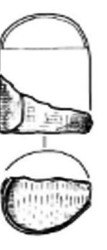

7

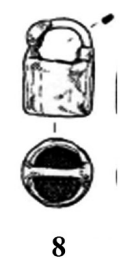

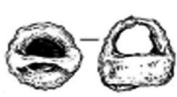

10

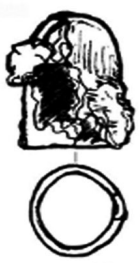

11
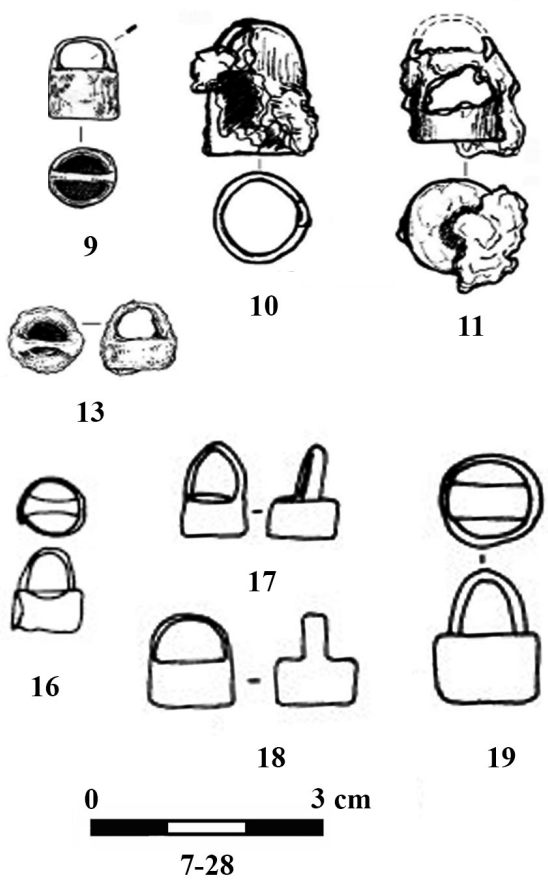

19

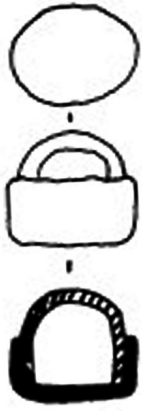

20
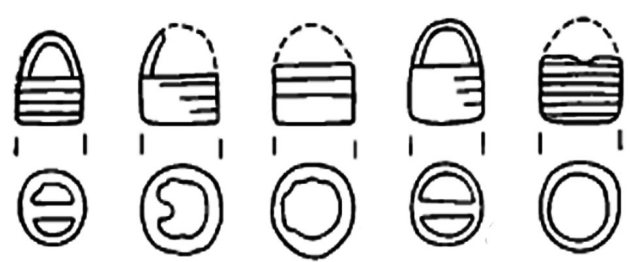

25

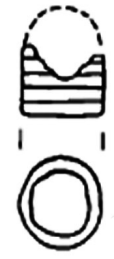

26

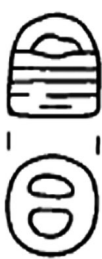

27

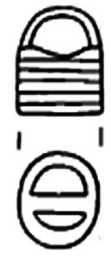

28

Fig. 7. Bucket-shaped pendants.

1, 7-13. Nejzats (after Stoyanova 2016);

2. Chellenitsya I (after Kotigoroshko 2015),

3. Suplacu de Barcău (after Gindele 2015);

4-5. Olbia (after Mordvintseva and Trejster 2007);

6. Ust'-Al'ma (after Puzdrovskij 2007);

14-16. București-Militari (after Bichir 1984);

$$
\text { 17-18. Poienești; }
$$

19-20. Pădureni (after Bichir 1973);

21-28. Solontsy (after Kotogoroshko 1987).

1-5. Gold; 7. Silver; 6. Bronze; 8-28. Iron. 1-5. Without scale. 